\title{
Comparing UK Tax Returns of Foreign Multinationals to Matched Domestic Firms ${ }^{\dagger}$
}

\author{
By KATARZYNA ANNA BILICKA*
}

In this paper, I use confidential UK corporate tax returns data to explore whether there are systematic differences in the amount of taxable profits that multinational and domestic companies report. I find that the ratio of taxable profits to total assets reported by foreign multinational subsidiaries is one-half that of comparable domestic standalones. The majority of the difference is attributable to the fact that a higher proportion of foreign multinational subsidiaries report zero taxable profits. I document how the estimated difference is related to profit shifting and show that using accounting data leads to much smaller estimates of the difference. (JEL F23, H25, H32, L25)

Aggressive tax avoidance and profit shifting by corporations has become more prominent in policy debates since the financial crisis. Governments see combating tax avoidance as one of the crucial means of recovering from the fiscal consequences of the crisis. For example, in 2015 the OECD countries agreed to jointly reduce the extent of profit shifting via the Base Erosion and Profit Shifting (BEPS) project. 1 The media has also shown increased appetite for "naming and shaming" many familiar multinational companies, such as Starbucks and Amazon, for paying too little tax.

To date, the debate has lacked a rigorous measure of how much the actual extent of profit shifting of multinational companies is. I use a unique administrative dataset of the universe of confidential corporate tax returns to consider the taxable profits that companies reported to the UK tax authorities (Her Majesty's Revenue

\footnotetext{
* Jon M. Huntsman Business School, Utah State University, 3500 Old Main Hill, Logan, UT 84322 (email: katarzyna.anna.bilicka@gmail.com) and Oxford University Centre for Business Taxation. Liran Einav was the coeditor for this article. I would like to thank Rosanne Altshuler, Jennifer Blouin, Steve Bond, Mike Devereux, Dhammika Dharmapala, Henrik Kleven, Daniela Scur, Johannes Voget, and three anonymous referees for their comments. This paper was previously circulated under the title "How Aggressive are Foreign Multinational Companies in Reducing Their Corporation Tax Liability? Evidence from UK Confidential Corporate Tax Returns." This work contains statistical data from HMRC which is Crown Copyright. The research datasets used may not exactly reproduce HMRC aggregates. The use of HMRC statistical data in this work does not imply the endorsement of HMRC in relation to the interpretation or analysis of the information. The author is also thankful for the support from the ETPF, the ESRC grant "The effects of business taxation on economic and social welfare: new insights from tax return data," ES/L000016/1 and the Peter G. Peterson Foundation for a postdoctoral fellowship on long-term fiscal policy at NBER during which part of this research has been conducted. The author declares that she has no relevant or material financial interests that relate to the research described in this paper.

${ }^{\dagger}$ Go to https://doi.org/10.1257/aer.20180496 to visit the article page for additional materials and author disclosure statement.

${ }^{1}$ For the OECD report, see http://www.oecd.org/ctp/beps.htm.
} 
and Customs-HMRC) during the period 2000 to $2014 .^{2}$ In particular, I focus on whether there are systematic differences in the ratio of taxable profits to total assets that UK subsidiaries of foreign multinational companies and standalone domestic UK companies report. I call this difference profit ratio gap. ${ }^{3}$ In order to appropriately account for the difference in the observable characteristics between those two ownership categories, I use propensity score matching approach. I "match" companies based on the size of their assets and industry in which they operate and find that foreign multinational subsidiaries underreport their taxable profits by 50 percent relative to domestic standalones. These estimates are large, but are still likely to be conservative. This is because no comparable domestic standalones exist for the very large foreign multinational subsidiaries. These excluded multinationals report much lower ratios of taxable profits to total assets than the smaller multinational firms in the matched sample.

This is the first study to use the administrative firm-level data to focus on multinational profit shifting practices and explore a new phenomenon, companies reporting exactly zero taxable profits. The majority of the previous literature on profit shifting has used accounting firm-level data to analyze the reporting behavior patterns of multinational companies (Egger, Eggert, and Winner 2010; Dischinger and Riedel 2011; Dharmapala and Riedel 2013; Dischinger, Knoll, and Riedel 2014; Gumpert, Hines, and Schnitzer 2016; and Dyreng et al. 2017). In the UK context, I find large bunching at zero taxable profits for foreign multinational subsidiaries relative to domestic standalones, which is not observed to the same extent in the accounting data. Multinational firms tend to report their taxable profits to be zero on their tax returns, while their accounting profits to be positive. This leads to much larger estimates of profit shifting behavior than previous literature using accounting data has offered. The observed bunching at zero taxable profits explains most of the profit ratio gap. Hence, reporting zero taxable profits is the most important margin for understanding the profit reporting behavior of multinational companies. Further, by using administrative data, I contribute to the growing literature examining profit reporting of companies using tax returns data (Grubert, Goodspeed, and Swenson 1993; Grubert 1998; Mills and Newberry 2004; Altshuler et al. 2009; Dowd, Landefeld, and Moore 2017) and Bureau of Economic Analysis survey data on US multinational corporations (Laster and McCauley 1994, Mataloni 2000, Clausing 2016).

One possible explanation for the large profit ratio gap is that multinational companies are able to use various methods of profit shifting, such as debt shifting, patent or royalty location, or transfer pricing to minimize their taxable profits in the United Kingdom. In contrast, I pick domestic firms as a comparison group, because they are unable to do so. Previous work on profit shifting has often focused on these profit shifting methods separately, while this paper takes a broader perspective. After examining the size of the gap, in the second part of the paper, I explore

\footnotetext{
${ }^{2}$ The United Kingdom has introduced the Diverted Profits Tax in April 2015 aimed at taxing profits shifted abroad by multinational companies: see http://bit.ly/1sFOLcc. The United Kingdom also announced limits to interest deductibility, one of many ways in which corporations minimize their tax payments, from April 2017: see the UK 2016 Budget, p. 56 (http://bit.ly/1R2QgNv).

${ }^{3}$ See Bilicka (2017) for a discussion of various alternative measures to compare profit reporting behavior of multinational and domestic companies.
} 
different channels that may explain the size of the observed profit ratio gap. First, I find that in the United Kingdom, domestic companies report 13.5 percentage points lower leverage than comparable multinationals and that 40 percent of the profit ratio gap can be explained by the differences in leverage. The observed importance of leverage in explaining the size of the profit ratio gap stands in contrast to the evidence from Heckemeyer and Overesch (2017) who discuss channels of profit shifting in their meta-analysis and show the prevailing importance of transfer pricing over financial planning. I have no information on goods traded within the multinational companies, hence, I am unable to address the question about the importance of transfer pricing directly. Cristea and Nguyen (2016); Liu, Schmidt-Eisenlohr, and Guo (2017); and Davies et al. (2018) provide detailed analyses of transfer pricing by using tax and trade linked datasets. Second, I show that multinational firms have more intangible assets than domestic firms and the size of profit ratio gap is largest for firms operating in sectors with highest intangible asset investments. This suggests that multinational firms in the United Kingdom use intangible assets location as another method to shift profits abroad.

The large number of zero taxable profit reporting foreign multinational subsidiaries may point toward a very aggressive form of profit shifting for some foreign multinationals. This is a new phenomenon that has previously not been explored in the literature. Johannesen, Tørsløv, and Wier (2016) and Dharmapala and Hebous (2018) are the two recent papers, which use accounting data to examine bunching around zero accounting profits. Johannesen, Tørsløv, and Wier (2016) shows that the size of this bunching varies depending on the tax rate differential to the headquarter and hence is related to profit shifting. Dharmapala and Hebous (2018) use the accounting data to obtain estimates of profit shifting using bunching methodology. Both of their findings are consistent with this paper.

The last part of the paper splits the analyzed sample across different firm characteristics and analyses heterogeneities in the profit ratio gap estimates. First, I find that the estimated profit ratio gap is largest for multinational firms headquartered in tax havens relative to multinational subsidiaries headquartered in higher tax rate countries. This is consistent with the findings of the previous literature which have shown a strong relationship between tax rates or firm structure, such as presence of tax havens, and profit reporting across jurisdictions (see Hines and Rice 1994; Grubert and Slemrod 1998; Desai, Foley, and Hines 2006; Slemrod and Wilson 2009; Egger, Eggert, and Winner 2010; Dischinger and Riedel 2011; Dharmapala and Riedel 2013; Dischinger, Knoll, and Riedel 2014; Gumpert, Hines, and Schnitzer 2016). It also allows me to link the estimated profit ratio gap with profit shifting, similar to the cited literature. Second, I find that in spite of declining top marginal tax rates in the United Kingdom the size of the estimated profit ratio gap increases over time. This suggests that the size of profit shifting increases over time and is consistent with findings of OECD in their BEPS report ${ }^{4}$ and Dowd, Landefeld, and Moore (2017). In contrast, Dharmapala (2014) shows that the literature using accounting data finds that the size of profit shifting declines over time. This inconsistency may have two sources. The increasing importance of zero taxable profit reporting in explaining

\footnotetext{
${ }^{4}$ For more details, see OECD: http://www.oecd.org/ctp/measuring-and-monitoring-beps-action-11-2015-finalreport-9789264241343-en.htm.
} 
the size of the profit ratio gap means that accounting data will be unable to capture that phenomenon. Further, as pointed out recently by OECD, ${ }^{5}$ Clausing (2016), and Tørsløv, Wier, and Zucman. (2018), this may also be traced to the near absence of tax haven observations in the accounting datasets.

The decline in the corporate tax rates in the United Kingdom together with an increasing size of the estimated profit ratio gap present a puzzle. If marginal cost of shifting profits abroad is equal to marginal benefits, we would expect a cut in the domestic corporate tax rate to reduce the marginal benefit of shifting profits abroad. This should induce a multinational company to report higher taxable profits in the United Kingdom. However, since the majority of multinational companies in the United Kingdom report no taxable profits, we expect those companies may be inelastic to changes in the corporate tax rates. One way to interpret this finding is that the cost of reducing taxable profits may not be a convex function of the firm's profits. Instead, firms in my sample may incur fixed cost of shifting profits. To show that the estimated profit ratio gap is related to changes in tax rates and hence, can be interpreted as a measure of profit shifting, I show that it is responsive to changes in foreign tax rates of multinational headquarters. I find that this change in the profit ratio gap is linked with an increase in the fraction of zero taxable profit reporting multinational subsidiaries in the United Kingdom when the tax rate in the headquarter decreases. This is consistent with the fixed cost of profit shifting hypothesis. These findings are also in line with recent evidence provided by Dowd, Landefeld, and Moore (2017) who show that the response of profit shifting to tax rate changes is highly nonlinear. They find that companies are much more likely to shift to havens with near-zero rates than to shift between two countries with moderate rates.

In what follows, Section I describes the data used in this paper, Section II outlines the empirical methodology and the challenges associated with it, Section III discusses the results, and Section IV concludes.

\section{Data Description and Sample Selection Criteria}

The primary data source used in this paper is the confidential universe of unconsolidated corporation tax returns in the United Kingdom for the years 2000-2014 provided by HMRC. The dataset comprises all items that are submitted on the corporation tax return form (CT600 form) and the unit of observation is an unconsolidated statement in each of the years, i.e., each subsidiary of a company operating in the UK files a separate tax return. I use these data to obtain information on the taxable profits variable. The HMRC data do not include any firm-level characteristics, apart from trading turnover. Therefore, I merge the HMRC data with the accounting data from the FAME dataset. FAME dataset, collected by Bureau van Dijk, provides balance sheet information for most of the UK companies. For instance, it gives me information on total assets, accounting profits, age of firms, number of employees, industry, and leverage.

Matching the HMRC data with accounting data restricts the sample size. I find a matched unconsolidated accounting statement in FAME for 76 percent of unconsolidated tax returns from the HMRC data, which include 89 percent of the

\footnotetext{
${ }^{5}$ For details, see BEPS Action Plan: https://www.oecd.org/ctp/BEPSActionPlan.pdf.
} 
total tax liability and 92 percent of total trading turnover in the United Kingdom. I ensure that I have non-missing total assets information and full 12 months accounting period for each matched HMRC-FAME observation.

I use the FAME ownership information to identify firms into two distinct ownership categories: UK subsidiaries of foreign multinational companies which are subsidiaries of multinational companies that have headquarters outside of the United Kingdom; and UK standalone domestic companies, which are independent companies with no affiliates. These two types of companies constitute about 30 percent of the total taxable profits in the United Kingdom and hold 50 percent of total assets. Their observable characteristics are similar to other types of multinationals and domestic companies, which makes them representative of the ownership classes they were chosen from. I have chosen those two groups of companies to find the two most comparable ownership groups, of which one has the ability to shift profits abroad (foreign multinational subsidiaries) and one does not (domestic standalones). 6

To strengthen the comparability between the two ownership categories, I limit the sample of foreign multinational subsidiaries to include only affiliates that have zero subsidiaries and that have positive trading turnover. The inclusion of affiliates that have no subsidiaries themselves ensures that the total assets number refers only to the operations of that single company and is consistent with the taxable income number from the tax returns. The reason for the concern is that the total assets number that firms report in their accounting statements often accounts for the equity value of their subsidiaries. Thus, the ratio of the taxable profits to total assets may be biased downward for companies that have subsidiaries relative to companies with no subsidiaries which report the same taxable profits. Further, I ensure that foreign multinational subsidiaries selected for the analysis report having positive trading turnover in the United Kingdom. This means that they have trading activities in the United Kingdom and do not exist solely as holding companies to transfer profits between company affiliates. It is important to note here that those two restrictions exclude affiliates which are part of complicated multinational structures, that are even more likely to be associated with aggressive tax avoidance behavior. Since those companies are likely to report even lower taxable profits, this means that the presented estimates are conservative. The total number of foreign multinational subsidiaries in the sample is 460,000 , of which 310,000 have no subsidiaries themselves and of those just under 230,000 also report to have positive trading turnover.

In my empirical analysis I do not consider domestic multinationals for two distinct reasons. First, one may think that they would be a good comparison group for foreign multinational subsidiaries. However, since domestic multinationals have similar opportunities to shift profits abroad as foreign multinationals do, the size of the difference in taxable profits between these two groups would not give me any information on the potential size of profit shifting. On the other hand, they may present an interesting comparison with domestic standalones. However, the size of the total assets of domestic multinationals in my dataset is not a good approximation of the size of their operations in the United Kingdom. This is because all but a few of

\footnotetext{
${ }^{6}$ The omitted ownership categories include domestic multinationals, which are multinational companies that have headquarters located in the United Kingdom; domestic and unidentified groups, which are companies for which I was unable to identify a foreign parent or the location of the parent; and missing ownership.
} 
the domestic multinational subsidiaries in the selected sample report total assets of at least one subsidiary on their balance sheet. Therefore, those companies might not be as comparable to domestic standalones in terms of the main variable of interest as foreign multinational subsidiaries without any subsidiaries are. Further, one-half of domestic multinationals report only consolidated accounts in the FAME dataset. An alternative would be to use trading turnover reported in the tax returns as a measure of size for domestic multinationals. However, this is not possible as trading turnover for domestic multinationals is almost always missing (likely because companies are not required to report turnovers). It means that I have no data source to approximate the size of domestic multinationals in the United Kingdom.

I also do not focus the empirical analysis on the differences between foreign multinational subsidiaries and domestic groups. The exclusion of domestic groups from the empirical analysis comes from the fact that I cannot identify those types of companies with certainty. I can say with confidence that they are not domestic standalones, but due to missing ownership data, it is entirely plausible that a company that I have classified as part of a domestic group is actually a foreign multinational subsidiary.

\section{A. Descriptive Statistics}

In this section I present descriptive evidence on the profit ratio gap. In Figure 1, I plot the weighted mean ratios of taxable profits to total assets for the two analyzed groups. Specifically, I sum up all taxable profits in each year for each ownership type and do the same for total assets. I then divide one sum over the other to obtain the weighted means. In panel A, I consider the whole sample of observations for both ownership types. In panel B, I consider only companies of similar size, excluding very large foreign multinational subsidiaries for which no comparable domestic standalones exist and excluding very small domestic standalones for which no comparable foreign multinational subsidiaries exist. In panel C, I further impose a restriction that the companies considered in panel B report positive taxable profits only.

I find that, in the raw data, domestic standalones report six to ten times higher ratio of taxable profits to total assets than foreign multinational subsidiaries. When I compare companies of similar sizes, they report more comparable taxable profits. The difference in the profit ratio gap in panel B is about 4 percentage points; foreign multinational subsidiaries report their ratio of taxable profits to total assets to be 8 percent, while domestic standalones report that to be 12 percent at the beginning of the sample period. Further, after excluding companies which report zero taxable profits, the difference in the profit ratio gap disappears. In the second half of the sample period, foreign multinational subsidiaries, which report positive taxable profits, actually report higher taxable profits than domestic standalones which report positive taxable profits.

\section{Empirical Methodology}

In this section I describe the empirical strategy I use to estimate the size of the profit ratio gap. First, foreign multinational subsidiaries are much larger than domestic standalones, hence a simple comparison of the mean ratios of taxable profits divided by total assets is likely to include companies that are not comparable. The evidence 
Panel A. All sample

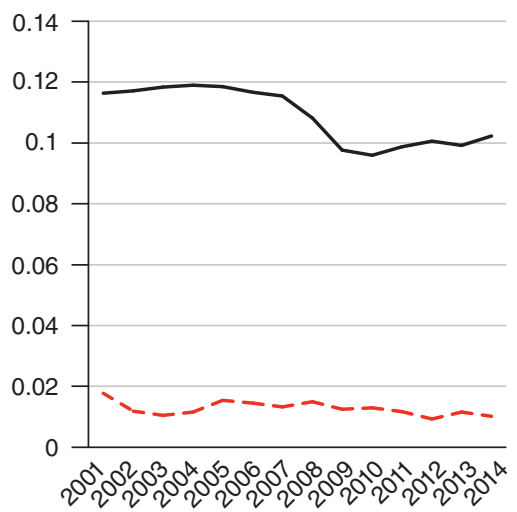

Panel C. Comparable size and positive taxable profits only

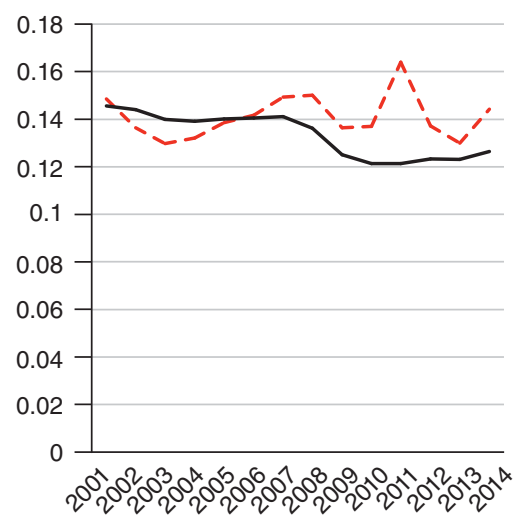

Panel B. Comparable size

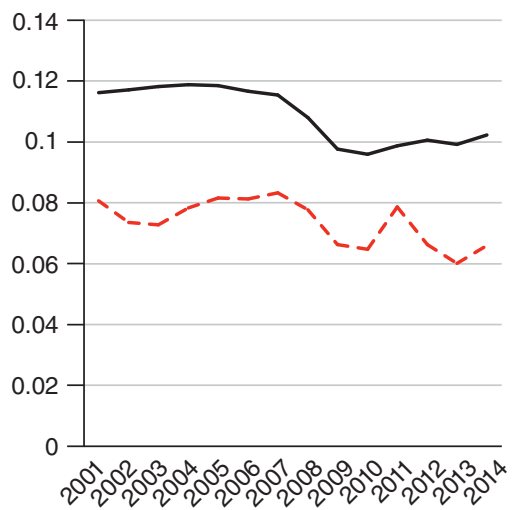

_- Foreign multinationals

Figure 1. Taxable Profits Comparisons: Foreign Multinational Subsidiaries versus Domestic Standalones

Notes: Differences in the ratio of taxable profits to total assets between foreign multinational subsidiaries and domestic standalones. The ratios are calculated by summing up all taxable profits of a particular ownership category in each year and dividing these by the sum of total assets of that particular ownership category in that particular year. Years used 2000-2014, selected sample.

Sources: Merged HMRC and FAME data

from Bilicka (2017) shows that very large multinationals report lower ratios of taxable profits to total assets than smaller multinationals for which comparable domestic standalones exist. Conversely, very small domestic standalones report higher ratios of taxable profits to total assets than larger domestic standalones for which comparable foreign multinational subsidiaries exist. Hence, the simple difference in means calculated for the whole sample may be upward biased. Second, foreign multinational subsidiaries and domestic standalones differ not only in terms of size, but also across other observable characteristics, such as productivity, size, and wages.7] This suggests that there may be a selection into being a multinational company that is a

\footnotetext{
${ }^{7}$ For empirical contributions, see Aitken and Harrison (1999); Javorcik (2004); Sabirianova, Svejnar, and Terrell (2005); and Yasar and Morrison Paul (2007). This endogeneity has also been explored theoretically by Markusen and Venables (1998) and Helpman, Melitz, and Yeaple (2004).
} 
function of observable firm-level characteristics. To alleviate the concerns about the comparability of the two ownership groups I use a nonparametric matching method. The nonparametric nature of the propensity score matching (PSM) is important since it avoids misspecification of the equation as could be the case with ordinary least squares (OLS). To obtain the OLS results similar to the matching ones, I would need to control for a fully flexible observed characteristics matrix.

In the first stage I estimate a logit model with a multinational dummy on the left-hand side and the determinants of being a multinational company on the righthand side. I use this regression to calculate the predicted probabilities of being a multinational company for each observation. These are called propensity scores (Rosenbaum and Rubin 1983, 1985; Imbens 2004). Formally,

$$
\text { multinational }_{i}=\alpha_{i}+\delta \mathbf{K}_{i t}+\text { ind }_{i}+\text { year }_{t}+\epsilon_{i t}
$$

where multinational $_{i}$ is a multinational dummy equal to 1 if a company is a multinational and 0 otherwise, $\mathbf{K}_{i t}$ is a set of determinants of being a multinational, ind and year $r_{t}$ are industry and year fixed effects. I use a nearest neighborhood matching strategy within a 0.1 caliper radius without replacement, which for each foreign multinational subsidiary finds a closest comparable domestic standalone within the 0.1 radius in terms of the propensity score. ${ }^{8}$ That particular domestic standalone is used only once, hence the sample size of foreign multinational subsidiaries and domestic standalones is the same. Further, I impose a common support restriction for total assets, hence no company larger than the largest domestic standalone and no company smaller than the smallest foreign multinational is in the sample. It is important to note here that the PSM approach requires the assumption that, once I control for the observable characteristics, the remaining characteristics do not affect the dependent variable. I cannot directly evaluate this assumption, hence my results are conditional on it. However, I show that they are robust to controlling for a variety of observable firm-level characteristics.

When calculating the profit ratio gap, the literature has suggested that the usual variance estimation may be inaccurate. The problem is that the estimated variance of the treatment effect should also include the variance due to the estimation of the propensity score, the common support and the order in which the treated individuals are matched. One way to deal with this problem, that has been used in the literature, is bootstrapping of standard errors. However, recently it has been shown that the bootstrap is not, in general, valid for matching estimators, especially the ones using a fixed number of matches (Abadie and Imbens 2006, 2008). Instead, Abadie and Imbens (2016) derive an adjustment to the large sample variance of propensity score matching estimators that corrects for first step estimation of the propensity score, which has been implemented in this paper.

The critical difficulty of this paper is in finding the most comparable group of companies with similar observable characteristics. In the baseline specification I

\footnotetext{
${ }^{8}$ Cochran and Rubin (1973) and Rosenbaum and Rubin (1985) suggest using a caliper width that is a proportion of the standard deviation of the logit of the propensity score, specifically 0.2 standard deviations was suggested to eliminate approximately 99 percent of the bias due to the measured confounders. Since the standard deviation of the logit of the propensity score is 0.5 in my baseline matching model, I choose 0.1 caliper width. I test the robustness of this matching approach in the Appendix.
} 
keep the set of matching variables as simple as possible and match companies based on their size as measured by total assets and within each industry and each year. 9 In the second stage of the propensity score matching, the profit ratio gap is estimated. This approach is applied to alternative outcome variables as well.

In Bilicka (2017) I documented large differences in the proportions of observations that report zero taxable profits between foreign multinational subsidiaries and domestic standalones. Therefore, the estimation of the unconditional means of the profit ratio gap is not the only interesting margin of comparison between the ownership types. The unconditional mean can be decomposed into the share of zeros and a mean conditional on reporting positive taxable profits in the following way:

$$
E(y)=(1-p) E(y \mid y=0)+p E(y \mid y>0)=0+p E(y \mid y>0)=p E(y \mid y>0)
$$

where $p=\operatorname{Pr}(y>0)$ and $y=$ taxable profits/total assets. This suggests dividing the analysis into three main components; the unconditional mean of taxable profits relative to total assets, the mean of taxable profits conditional on reporting positive taxable profits and the binary outcome analysis of zero taxable profit reporting that will directly estimate $p$. Dropping observations with $y=0$ and performing PSM is the most straightforward way to analyze the conditional mean, while selectivity correction may be considered a refinement.

The difference in the PSM estimate between the unconditional and conditional means indicates how much of the difference in taxable profits between foreign multinational subsidiaries and domestic standalones I can attribute to zero taxable profit reporting. Furthermore, I consider zero taxable profits dummy defined as 1 when the company is reporting zero taxable profits and 0 otherwise as an outcome variable. The results from that estimation will tell me the difference in the proportion of observations that are reporting zero taxable profits between the two ownership types in the matched sample.

The question also arises whether we are only interested in taxable profits as they are recorded on the tax return form, i.e., taxable profits $=\max (0$, taxable income $)$, or whether we are also interested in the underlying taxable income, which may be either positive or negative. This is conceptually unclear, given the asymmetric treatment of profits and losses. In the UK tax system when a company makes a loss it does not receive a tax credit on that loss, but instead records zero taxable income and hence pays no corporation tax on that income. It is then allowed to bring some of the losses it made forward into future periods and offset them against positive taxable profits, once it is profitable again. Alternatively, it can also bring the losses back one period and offset them against last year's profits, if those profits were positive. In case of loss carryback the company would receive tax credit in that particular year. When taxable profits are positive, the corporation tax liability is paid. This means that the taxable profits are censored at zero.

What this implies for the purpose of this paper is that with fully symmetric treatment, we would only be interested in the underlying taxable income, with fully asymmetric treatment (no carry back or carryforward of losses), we would only be

\footnotetext{
${ }^{9}$ I check the robustness of the choice of the baseline matching variables in the Appendix.
} 
interested in the recorded taxable profits (censored at zero). With the actual treatment (some carry back and carryforward at nominal value) we may be interested in both. We can potentially use additional information from the tax return, e.g., on losses, to recover or estimate the underlying taxable income. One of the possible sources of information is trading losses in the CT600 form, where firms have to report the amount of losses arising from their trading activities. The advantage of this measure is that we could simply subtract those trading losses from recorded taxable profit to recover some of the underlying taxable income. The disadvantage is that we have no information on other sources of losses that companies may be incurring, which means that we are introducing a measurement error into the analysis. Those other sources of losses are, for instance, non-trading losses on intangible fixed assets or non-trading losses on loan relationships including interest and derivative contracts (financial instruments). In the empirical analysis I focus on the censored taxable profits for the baseline results and use the recorded taxable profits measure when I analyze differences between taxable and accounting profits.

\section{Results}

In the first stage of propensity score matching I create a matched sample of foreign multinational subsidiaries and comparable domestic standalones. In Table 1, I show means of total assets, trading turnover and age for the whole sample, matched sample and unmatched sample, where unmatched sample consists of observations for which I found no comparable companies after propensity score matching. The differences in means of the main observable firm level characteristics between the two ownership types are large and significant in the whole sample, but insignificant in the matched sample. Hence, matching procedure makes the two groups more comparable. Foreign multinational subsidiaries in the matched sample are on average smaller and younger than in the whole sample, while domestic standalones are larger and older.

In Table 2, I present results from the baseline propensity score matching. I consider an unconditional mean of taxable profits relative to total assets (baseline sample) and a conditional mean of taxable profits relative to total assets (positive taxable profits sample). Column 3 in Table 2 shows the mean ratio of taxable profits to total assets for the treated group: foreign multinational subsidiaries; while column 4 shows the mean ratio of taxable profits to total assets for the control group: domestic standalones. Column 5 shows the difference between the two means and the last two columns show the standard errors and the total number of observations in both treated and control groups.

The estimates of the profit ratio gap are negative and highly significant in all specifications. The mean ratio of taxable profits to total assets for foreign multinational subsidiaries is 12 percent while that same ratio is 24 percent for domestic standalones. This implies that foreign multinational subsidiaries report 50 percent lower ratio of taxable profits to total assets. I test the robustness of these findings in the Appendix and find that they are robust to controlling for variety of additional observable controls, using different firm size proxies, consolidating profits at a multinational group level, and using different matching algorithms. 
TABle 1 -Summary Statistics

\begin{tabular}{lcc}
\hline \hline & $\begin{array}{c}\text { Foreign } \\
\text { multinationals }\end{array}$ & $\begin{array}{c}\text { Domestic } \\
\text { standalones }\end{array}$ \\
\hline Whole sample & & \\
log total assets & 14.11 & 10.89 \\
Total assets (million) & 16.05 & 0.26 \\
Trading turnover (million) & 14.39 & 0.85 \\
log trading turnover & 14.17 & 11.41 \\
Age & 18.31 & 11.32 \\
& & \\
Matched sample & & \\
log total assets & 13.52 & 13.58 \\
Total assets (million) & 2.26 & 2.49 \\
Trading turnover (million) & 4.03 & 4.46 \\
log trading turnover & 13.90 & 13.84 \\
Age & 17.22 & 19.42 \\
Unmatched sample & & \\
log total assets & & \\
Total assets (million) & 14.50 & 10.84 \\
Trading turnover (million) & 25.04 & 0.21 \\
log trading turnover & 21.15 & 0.77 \\
Age & 14.35 & 11.36 \\
\hline
\end{tabular}

Notes: Unweighted means of observed firm-level characteristics: comparison of whole, matched, and unmatched samples for foreign multinational subsidiaries and domestic standalones. Matched sample is created using propensity score matching. Unmatched sample is the whole sample minus matched sample. The differences in the means of the observable firm level characteristics between foreign multinational subsidiaries and domestic standalones are significant in the whole and unmatched samples. In the matched sample, the differences in the means of observable firm-level characteristics between foreign multinational subsidiaries and domestic standalones are insignificant for total assets, trading turnover, and age; 2000-2014, selected sample. Trading turnover and total assets are in millions of pounds.

Sources: Merged HMRC and FAME data

Further, foreign multinational subsidiaries are 30 percentage points more likely to report zero taxable profits in the matched sample; 50.5 percent of foreign multinational subsidiaries and 20.5 percent of domestic standalones report zero taxable profits. When restricting the sample to companies which report positive taxable profits only, the profit ratio gap falls from 12 percentage points to 4.9 percentage points. This implies that 60 percent of the average profit ratio gap is explained by the fact that a higher proportion of foreign multinational subsidiaries report zero taxable profits. Hence, once foreign multinational subsidiaries decide to report positive taxable profits, their reporting behavior is a lot more comparable to that of domestic standalones.

Moreover, a puzzle emerges, as I cannot identify any major differences in the observable firm-level characteristics between taxpayers and non-taxpayers. This may suggest that firms instead differ in their unobservable characteristics such as their ability to shift profits or reputational costs of aggressive tax planning. ${ }^{10}$

\footnotetext{
${ }^{10}$ The accounting literature identifies a relationship between firm's CEO who may be an aggressive tax planner and the amount of accounting profits that a firm reports (Armstrong et al. 2012, 2015).
} 
Table 2-Propensity Score Matching: Baseline Results

\begin{tabular}{lcccccc}
\hline \hline Sample & Variable & Multinational & Domestic & Diff. & SE & Observations \\
\hline Baseline & $y$ & 0.120 & 0.238 & -0.119 & 0.011 & 324,736 \\
Baseline & $y>0$ & 0.236 & 0.285 & -0.049 & 0.020 & 170,520 \\
Baseline & $z t p$ & 0.505 & 0.205 & 0.300 & 0.001 & 324,736 \\
Positive taxable profits & $y$ & 0.234 & 0.283 & -0.049 & 0.020 & 170,798 \\
\hline
\end{tabular}

Notes: Results from the baseline propensity score matching estimation, 2000-2014, selected sample. Matching on total assets and within industry and year. Baseline sample estimates unconditional means, positive taxable profits sample estimates means conditional on positive taxable profits, $y$ is the ratio of taxable profits to total assets, $z t p$ is zero taxable profits. Treated observations are foreign multinational subsidiaries, control observations are domestic standalones. Observations column is a sum of total number of observations, which are split equally between the two ownership types.

Sources: Merged HMRC and FAME data

\section{A. Comparison of Taxable and Accounting Profits}

In this section I examine the differences in the profit ratio gap depending on whether we use taxable or accounting profits. The difference between what companies report on their accounting statements and in their tax returns is to be expected due to the differences in accounting standards and tax reporting standards. ${ }^{11}$ The three main differences arise due to different treatment of depreciation, inventories, and cash versus accrual accounting. First, accounting depreciation tends to be less generous than tax depreciation, which means that after taking into account capital allowances, accounting profits are expected to be higher than taxable profits (Desai and Dharmapala 2009, Hanlon and Heitzman 2010). Second, using different methods of accounting for inventories can reduce taxable income of companies relative to their accounting profits. Third, differences between recording activities using cash basis for tax purposes and accruals for accounting purposes can generate differences between tax and accounting profits. However, these three types of rules are the same for all types of companies, irrespective of whether they are domestic or multinational. Therefore, we would not expect them to affect the differences between the two measures of profits differentially between the ownership types.

Another source of difference between taxable and accounting profits can arise from opportunistic reporting of both types of profits (Hanlon 2003). In their accounting statements firms may use provisions for aggressive tax avoidance practices or tax shelters that they do not disclose publicly. These provisions might artificially inflate the reported accounting profits relative to the actual profits subject to taxes, or reduce taxable profits relative to accounting profits. Since this opportunistic reporting is often associated with the presence of tax shelters for multinational firms, it has been suggested in the literature that firms that are more tax aggressive, may have larger discrepancies between their tax and accounting profits. This can put a wedge between taxable and accounting profits for multinational firms that can be associated with profit shifting.

\footnotetext{
${ }^{11}$ This branch of the literature considers what is called a book-tax gap. See early contributions by Mills, Newberry, and Trautman (2002) and excellent summaries of research by Hanlon and Heitzman (2010); Graham, Raedy, and Shackelford (2012); and most recently Evers, Meier, and Nicolay (2017).
} 
Panel A. Foreign multinational subsidiaries

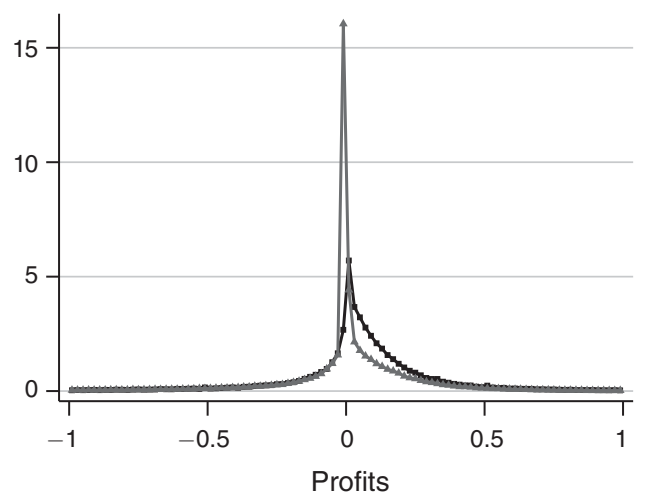

Panel B. Domestic standalones

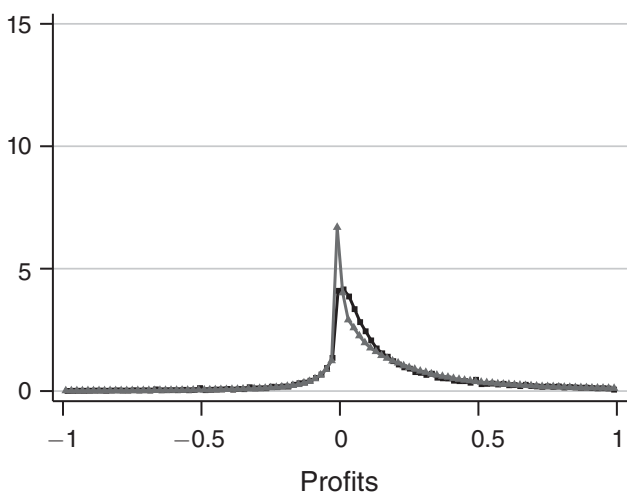

Figure 2. Distributions of TaXable and Accounting Profits: Comparisons

Notes: Distribution of the ratios of taxable profits (including trading losses) from HMRC and profit and loss before taxes from FAME scaled by total assets, propensity score matched sample with non-missing accounting profits data, 2000-2014. Gray line shows distribution of the ratio of taxable profits to total assets, while the black line shows the distribution of the ratio of accounting profits to total assets.

Sources: Merged HMRC and FAME data

Since taxable profits are censored at zero, while accounting profits can take negative values, to compare taxable and accounting profits directly I use two distinct approaches. The first method takes trading losses from the tax returns and subtracts them from taxable profits to recover the negative portion of taxable profits and obtains a measure which is closer to the current taxable profits. The second method converts all negative accounting profits into zeros, effectively censoring them in the same way as taxable profits are censored in the tax returns.

The baseline estimate of the profit ratio gap suggests that the main source of the difference lies in the proportions of observations reporting zero taxable profits. Therefore, in Figure 2 I focus on the comparison between distributions of taxable profits less trading losses and profit and loss before taxes, both scaled by total assets, to directly look at what happens around zero profits. Figure 2 contains two panels, each plotting the distributions of the ratios of both taxable (gray line) and accounting (black line) profits to total assets: panel A shows the comparison for foreign multinational subsidiaries and panel B for domestic standalones. Each figure shows the connected graphs using histograms of 100 bins of equal size in the range of profits between -1 and 1 . The horizontal axis in those figures shows the ratios of profits to total assets, while on the vertical axis we have the proportion of observations in each distribution bin.

First, accounting profits seem to be a better approximation for taxable profits of domestic standalones (panel B) than foreign multinational subsidiaries (panel A). Second, bunching around zero profits is prevalent in both accounting data (as shown by Johannesen, Tørsløv, and Wier 2016 and Dharmapala and Hebous 2018) as well as tax returns data. What is more interesting is that bunching around zero is much larger for taxable profits relative to accounting profits for foreign multinational subsidiaries than for domestic standalones. In addition, foreign multinational 
subsidiaries bunch around zero taxable profits to a larger extent than domestic standalones. In contrast, there is very little difference in bunching around zero accounting profits between foreign multinational subsidiaries and domestic standalones. Third, zero taxable profit reporting companies appear to come from the missing mass to the right of the taxable profits distribution, where the accounting profits distribution indicates that companies report much higher ratio of accounting profits to total assets. This suggests that accounting profits may overestimate taxable profits, especially in the case of foreign multinational subsidiaries. This is consistent with the hypothesis that multinational firms may engage in opportunistic reporting behavior that reduces their taxable profits relative to accounting profits.

Further, the extent of bunching at zero taxable profits has increased substantially for multinational companies over the sample period duration (see Figure 4 in the Appendix). The same has not occurred for domestic standalones. The missing mass to the right-hand side of the taxable profits distribution has become more pronounced over time, suggesting that accounting profits may overestimate taxable profits even more so in 2013 than they did in 2001, especially for foreign multinational companies.

The results from the distribution graphs are confirmed by the propensity score matching results. In Table 3, using the first method of comparison described above, I find that the profit ratio gap is -10.9 percentage points (row 3 ), while the difference in the ratio of accounting profits to total assets on the same sample is -6.6 percentage points (row 4). Using the second method, I find the profit ratio gap to be -5.6 percentage points (row 1), while the difference in accounting profits is -2.1 percentage points (row 2). In both cases the estimates of the profit ratio gap are substantially smaller when using accounting profits data than using taxable profits data. What is more, the ratios of taxable profits to total assets for foreign multinational subsidiaries are substantially smaller than the ratios of accounting profits to total assets for both methods. This suggests that the previous estimates of profit shifting obtained using accounting data are underestimating the true size of profit shifting of foreign multinational companies. Since the matching results are largely driven by the zero taxable profit reporting companies, this is not at all surprising. Foreign multinational subsidiaries seem to be reporting positive profits in their accounts, while at the same time reporting zero taxable profits on their tax returns. This would bias the estimates of profit shifting obtained using accounting data downward.

\section{B. Channels Companies Use to Lower Their Taxable Profits}

In this section I explore three potential factors driving the wedge in the profit ratio gap: leverage, productivity, and intangible assets. For each potential channel that companies may be using to reduce their taxable profits, I use that channel as an outcome variable in the baseline propensity score matching to explore the direct differences between ownership types. In addition, the propensity score matching approach allows me to calculate the proportion of the profit ratio gap that can be attributed to the differences in particular observable variables. To do so, in the first stage of PSM I use that variable as a matching variable. The difference in the matching estimates with and without that additional variable (on the same sample) will give me the fraction of the profit ratio gap explained by that observable. 
Table 3-PSM Results: Comparison of TAXable and Accounting Profits

\begin{tabular}{lccccc}
\hline \hline Variable & Multinational & Domestic & Diff. & SE & Observations \\
\hline$y$ & 0.080 & 0.136 & -0.056 & 0.0012 & 141,660 \\
Non zero acc $y$ & 0.124 & 0.145 & -0.021 & 0.0008 & 141,660 \\
$y$ (incl loss) & 0.002 & 0.112 & -0.109 & 0.0062 & 141,660 \\
Acc $y$ & 0.062 & 0.128 & -0.066 & 0.0011 & 141,660 \\
\hline
\end{tabular}

Notes: Results from the Propensity Score Matching estimates using total assets and within industry matching. Rows 1-2 and 3-4 are directly comparable. In row 1, I use taxable profits divided by total assets $(y)$ as an outcome variable. In row 2, I use profit and loss before taxes, where all negative values were turned to zero, and in row 3 , I use taxable profits measure from the tax returns data from which I subtract trading losses. In row 4, I use profit and loss before taxes from accounting statement without any adjustments. Treated observations are foreign multinational subsidiaries, control observations are domestic standalones. Selected sample, 2000-2014 with non-missing accounting profits observations. Observations column is a sum of total number of observations, which are split equally between the two ownership types.

Sources: Merged HMRC and FAME data

First, I consider the amount of debt that companies can take on, as leverage can be used as a tax shield by all companies. Multinational companies can derive additional benefit from using higher leverage due to tax benefits associated with locating debt in high tax countries. An affiliate of a multinational company in a high tax country can borrow from low tax subsidiaries and use deductibility of interest expenses to reduce its taxable profits in high tax country. Since the United Kingdom was a relatively high tax country for a majority of the sample period, locating debt in the United Kingdom was advantageous for multinational companies (also due to low interest rates and controlled foreign corporation (CFC) rules).

In particular, in Table 4 I look at the stock measure of gearing, i.e., total liabilities divided by total assets. This measures the external leverage of each firm in the sample and is the best measure available. I do not have a measure of intra-company borrowing; hence, I am unable to examine how much companies borrow from their affiliates. However, there is evidence in the literature that policies that are aimed at affecting intra-firm borrowing of firms also affect their external leverage (see Blouin et al. 2014 and Bilicka, Qi, and Xing 2019). Hence, firm internal and external borrowing patterns are closely related and patterns I see in external borrowing will likely be reflected in intra-firm borrowing too. Using leverage as an outcome variable, I find that foreign multinational subsidiaries take on about 13.5 percentage points more debt than comparable domestic standalones. Further, when I use leverage as an additional matching variable, I find that the profit ratio gap is -2.7 percentage points, which is about 60 percent of what it is when matching on total assets only, on the sample of observations with non-missing data on leverage ( -4.5 percentage points). This would suggest that leverage explains 40 percent of the profit ratio gap.

Higher leverage makes zero taxable profits more likely. Hence, differences in leverage and the proportion of zero taxable profits cannot be considered as separate factors. When restricting the sample to companies which report positive taxable profits, the difference in leverage between ownership types is reduced to 6 percentage points. This is consistent with the hypothesis that some companies use leverage to reduce their taxable profits to zero. 
TABLE 4-PSM: CHANNELS

\begin{tabular}{lcccc}
\hline \hline Channel & $\begin{array}{c}\text { Diff. in } \\
\text { channel }\end{array}$ & $\begin{array}{c}\text { Diff. } \\
\text { in } y\end{array}$ & $\begin{array}{c}\text { Diff. in } y \text { controlling } \\
\text { for channel }\end{array}$ & Observations \\
\hline Leverage & 0.135 & -0.045 & -0.027 & 125,614 \\
TFP & $(0.002)$ & $(0.001)$ & $(0.001)$ & 53,126 \\
Leverage and TFP (leverage) & 0.081 & -0.069 & -0.048 & 33,594 \\
Leverage and TFP (TFP) & $(0.003)$ & $(0.002)$ & $(0.002)$ & 33,594 \\
& 0.105 & -0.03 & -0.019 & $(0.002)$ \\
\hline
\end{tabular}

Notes: Results from the Propensity Score Matching estimates showing channels which companies use to reduce their taxable profits. Results show the difference in the PSM estimator between foreign multinational subsidiaries and domestic standalones. In column 2, the outcome variable is the channel, in row 1 that is leverage. In columns 3 and 4 , the outcome variable is the ratio of taxable profits to total assets. The results in column 3 replicate baseline PSM, but only on the sample for which the channel variable data is available, the results in column 4 use the channel as additional matching variable to total assets and industry. Standard errors of the estimated difference are in parentheses. Observations column is a sum of total number of observations, which are split equally between the two ownership types. Selected sample, 2000-2014.

Source: Merged HMRC and FAME data

I provide an additional piece of evidence to show that the differences in leverage between ownership types are related to profit shifting. The United Kingdom has been a high tax country for the majority of my sample period. However, in recent years the United Kingdom has undergone large corporate tax rate cuts that lowered its headline corporate tax rate from 30 percent in 2007 to 20 percent in 2015. This means that it has moved from a high tax country status to a relatively low tax country status. Locating debt in the United Kingdom is now less advantageous than it was for multinational companies. In accordance with this, the importance of leverage in explaining the size of the profit ratio gap has declined.

In Table 10, I compare the results from propensity score matching for years 20042014. I perform the same analysis as in Table 4 for every year in the sample. I find that leverage used to explain around 50 percent of the profit ratio gap before 2008 . This has substantially fallen to around 25 percent in the years after 2010. Further, the differences in leverage between multinational and domestic companies have fallen down substantially from 0.145 before 2008 to 0.116 after 2010 . This evidence is consistent with the fact that the lower the tax rate, the less likely multinationals are to locate their debt in the United Kingdom, if they are using debt to reduce their taxable profits. Hence, over time as tax rates in the United Kingdom fall, differences in leverage are becoming less important as a channel to explain profit ratio gap and hence, less important as a channel to explain profit shifting.

Second, I show that foreign multinational subsidiaries report to have significantly higher productivity than domestic standalones. To investigate this I calculate total factor productivity (TFP) for each firm in the sample, which measures the portion of output not explained by the amount of inputs used in production. Here, I use a measure of TFP based on value added, which subtracts capital and labor inputs from firms outputs to measure the productivity residual, i.e., $T F P_{i t}=v a_{i t}-\left(1-s l_{i t}\right) \times k_{i t}-s l_{i t} \times l_{i t}$; where $v a_{i t}$ is logarithm of value added, 
where value added is measured as a sum of wages and salaries and profit and loss before interest, $s_{i t}$ is share of labor, which is a ratio of wages and salaries divided by value added, $k_{i t}$ is logarithm of fixed assets, $l_{i t}$ is logarithm of number of employees and $i$ and $t$ refer to firm and year.

When matching on total factor productivity, the profit ratio gap falls from -0.69 to -0.48 . Foreign multinational subsidiaries are more productive than domestic standalones, yet conditional on having similar productivity levels they report lower taxable profits to total assets ratio than domestic standalones. The estimates presented here suggest that around 30 percent of the profit ratio gap is explained by differences in productivity between firms. ${ }^{12}$ These results suggest that more productive firms report lower taxable profits and engage in more profit shifting. This finding is closely related to the documented differences between taxable and accounting profits. To measure TFP I use profit from accounting statements to be consistent with the wages and fixed assets data. However, in Section IVA, I show that multinational firms have the largest wedge between tax and accounting profits and explain how this wedge may be related to profit shifting. Since TFP is closely related to the profitability measure from accounting statements, firms with larger TFP have larger gaps between their tax and accounting profits and may also be those shifting more profits. Finally, note that matching on both TFP and leverage together does not explain more than 40 percent of the gap in taxable profits between the ownership types.

The third channel I explore is the role of intangible assets. These assets play a large role in profit shifting, since it is relatively easy for companies to locate them in lower tax jurisdictions (Grubert 2003 and Dischinger and Riedel 2011). Using the ratio of intangible assets to total assets as an outcome variable in PSM, I find that foreign multinational subsidiaries have about 13.8 percentage points higher holdings of intangible assets than comparable domestic standalones. Since profit shifting strategies would involve locating intangible assets in low tax jurisdictions and moving them away from the United Kingdom, we would not expect intangible asset holdings in the United Kingdom to explain any variation in the profit ratio gap.

In the absence of information on intangible assets held abroad, I use comparison of profit ratio gap across sectors to shed light on the importance of intangible assets. Some sectors rely on the use and development of intangible assets more heavily. The Office for National Statistics (ONS) in the United Kingdom has recently released an industry breakdown of investment in intangible assets. ${ }^{13}$ These estimates show that the largest intangible investment as a proportion of Gross Value Added in the United Kingdom over the period 2000-2014 was done by firms in financial services and information and communication sectors, while the lowest in agriculture and construction sectors. Firms operating in those sectors are likely to have larger holdings of intangible assets located in low-tax jurisdictions. Multinational subsidiaries of those firms in the United Kingdom will make payments to their low tax affiliates for

\footnotetext{
${ }^{12}$ It is important to note that the ratios of taxable profits to total assets that were used to calculate the differences in taxable profits in Table 4 for both ownership groups are much lower than in the sample analyzed in the baseline matching. This is because I only have information on leverage, intangible assets, and TFP for larger firms, which tend to report lower ratios of taxable profits to total assets.

${ }^{13}$ The data come from the Office for National Statistics (ONS) dataset called "Experimental Estimates of Investment in Intangible Assets in the UK." (https://www.ons.gov.uk/economy/economicoutputandproductivity/ productivitymeasures/datasets/experimentalestimatesofinvestmentinintangibleassetsintheuk)
} 

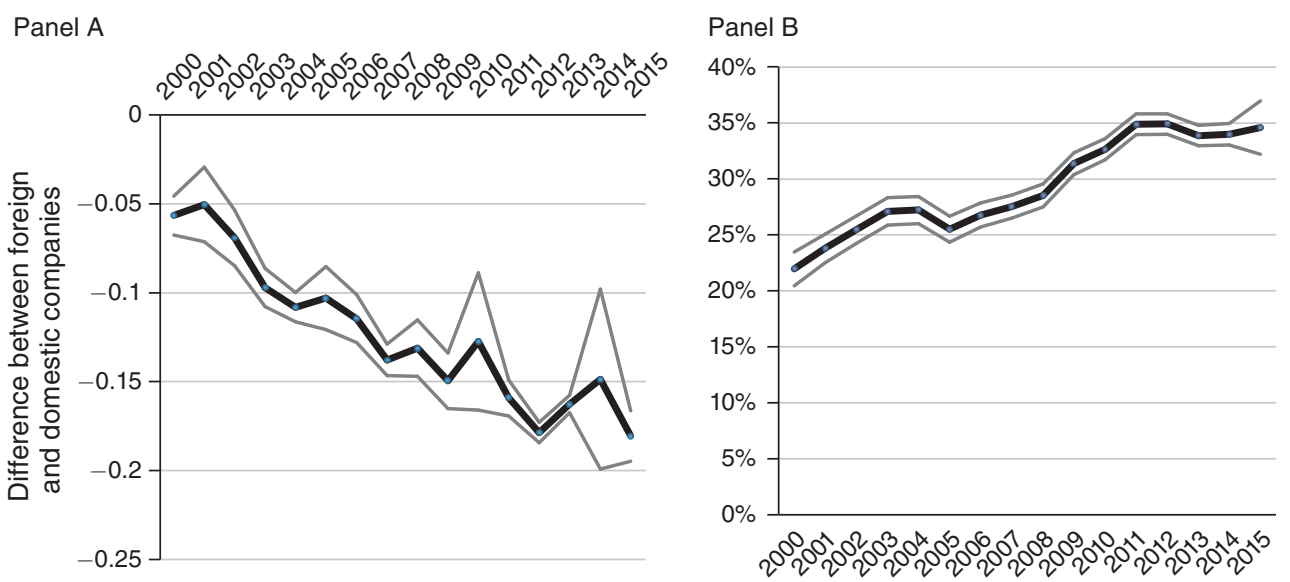

Figure 3. PSM: YeARLY Heterogeneity

Notes: Results from the Propensity Score Matching estimated year by year. PSM using total assets and within each industry. Panel A: the outcome variable is the ratio of taxable profits to total assets. Panel B: the outcome variable is zero taxable profits dummy. The estimated coefficients for each year are significant. Selected sample, 2000-2014.

Sources: Merged HMRC and FAME data

the use of those intangibles and these payments would reduce their taxable profits in the United Kingdom. Hence, if multinational firms use intangible assets located in low tax jurisdictions to reduce their taxable profits, I expect the largest profit ratio gap to be in place for firms in sectors that rely on intangible assets most heavily. Consistent with this hypothesis, I estimate the largest profit ratio gap for services $(0.17)$, followed by finance and insurance $(0.15)$, while the smallest gap is estimated for wholesale trade and construction $(0.07)$. Note that the ONS industry classification differs from the HMRC one, so I picked only sectors that I was able to compare directly. Those estimates are statistically significant at 1 percent level and suggest a profit ratio gap of around 70 percent for services and 45 percent for wholesale trade.

\section{Heterogeneity of the Estimated Coefficients}

In this section I explore the heterogeneity of the baseline estimates of the profit ratio gap. I specifically focus on two aspects of heterogeneity; first, I discuss changes in the estimated size of the difference over time and then I discuss differences between foreign multinational subsidiaries depending on the location of their headquarters.

To examine changes in the size of the profit ratio gap over time, I estimate the PSM for each sample year separately and calculate the difference in the ratio of taxable profits to total assets between the ownership types for each of the years 2000-2014. I then plot those estimates alongside the confidence intervals in Figure 3. In addition to the ratio of taxable profits to total assets, I also plot the estimates of the differences in the proportions of zero taxable profits between foreign multinational subsidiaries and domestic standalones.

The size of the profit ratio gap has increased from -5.6 percentage points in 2000 to -18 percentage points in 2014 with some fluctuations around the financial crisis. This increase can possibly be attributed to a constantly increasing difference in the 
fraction of zero taxable profit reporting companies. This has increased from 22 percentage points in 2000 to 35 percentage points in 2014. This is consistent with the recent evidence on the increase in profit shifting over time provided by the OECD BEPS studies and by Clausing (2016). This increase is likely due to the spread of avoidance techniques with improvements in digital technology, even as tax rate differences between countries have narrowed. In contrast, the evidence from accounting data (Dharmapala 2014) does not show the same increase in profit shifting.

The overall increase in the size of profit ratio gap over time is consistent with the evidence I presented on the decrease in the importance of debt shifting in the United Kingdom. It is entirely plausible that the extent of the use of two other channels of profit shifting, i.e., transfer pricing and patent and royalty location, has increased over time. The evidence from Liu, Schmidt-Eisenlohr, and Guo (2017), who use UK trade and tax linked datasets, shows that the extent of transfer pricing has increased substantially after the United Kingdom changed from worldwide to territorial tax system in 2009, with multinationals shifting more profits into low-tax jurisdictions. Their findings lend support to the proposed explanation.

This finding may be considered surprising in the context of the United Kingdom cutting its headline corporate tax rate from 30 percent in 2007 to 20 percent in 2015. For a company for which the marginal cost of shifting its taxable profits out of the United Kingdom is equal to the marginal benefit, we would expect that a cut in the domestic corporate tax rate would induce subsidiaries of foreign multinational companies to report more taxable profits in the United Kingdom, if the tax rates in other countries in which they have affiliates remained the same. This is because the marginal cost of reporting lower taxable profits in the United Kingdom increases following the domestic corporate tax rate cut. However, it may well be that foreign multinational subsidiaries do not respond to the UK corporate tax rate cuts, because the benefit they accrue from reducing their taxable profits in the United Kingdom is not a convex function of their profits. Instead, they have fixed cost of shifting profits, i.e., upfront cost of engaging in tax planning. This could be cost of setting up a business in a particular country, or cost of having related party transactions that does not depend on the amount of profits shifted, but rather on the level of enforcement in a country, the size of affiliate and other firm characteristics that may include, for instance, the unobservable propensity to shift profits (Dharmapala 2014).

Large companies with elaborate profit shifting strategies in place may be inelastic to changes in the tax rates, insofar as they already report zero taxable profits. The reduced tax rate would not offer them incentive high enough to exceed the fixed cost of switching to a different tax planning strategy to report higher (or even positive) taxable profits in the United Kingdom. This is consistent with a large and continuously increasing fraction of foreign multinational subsidiaries that report zero taxable profits in the United Kingdom. Further, the majority of the difference in taxable profits between multinational and domestic companies is explained by companies reporting little to no taxable profits. For those companies the UK tax system has a lower corporate tax rate of 19-20 percent that has been in place since 2006 .

I show that the size of the estimated profit ratio gap is sensitive to changes in foreign tax rates. This validates that the described measure is related to profit shifting and allows me to relate my study to the larger literature estimating the effect of tax rates on international shifting. I compare the size of the gap in taxable profits 
between foreign multinationals headquartered in Germany and UK domestic companies relative to foreign multinationals headquartered in France. In particular, I consider the period 2004-2010 during which Germany has cut its main statutory corporate tax rate from 25 percent $(38.4$ percent including surcharges and local taxes) to 15 percent (29.5 percent including surcharges and local taxes) in 2008, while French tax rate remained unchanged at 33.33 percent.

If the profit ratio gap measures profit shifting, we expect it to be affected by changes in the size of the tax rate differential between the United Kingdom and the country where the multinational has its other affiliates. In particular, if the tax rate in Germany falls, we would expect German companies to keep more profits in Germany. Hence, they may be less likely to shift profits into their UK subsidiaries or they may be shifting more back to Germany from their UK subsidiaries. This would reduce their taxable profits in the United Kingdom and the size of the profit ratio gap should increase across all tax brackets. I find that the size of the profit ratio gap for German multinational companies was -0.098 before the 2008 reform and increased to -0.13 after the 2008 tax rate cut. In contrast, the size of the profit ratio gap for French multinational companies was -0.12 before the 2008 reform and has fallen to -0.09 after the 2008 reform. The size of those estimated gaps is statistically significant at 1 percent level. Hence, the gap has significantly increased by 4 percentage points for German companies relative to French companies after the 2008 tax rate cut in Germany.

Further, I find that the average difference in the fraction of zero taxable profit reporting firms between German affiliates and UK domestic firms was 26.2 percentage points before the reform and increased to 29.2 percentage points after the reform. This same fraction has only increased from 25.8 percentage points to 26.7 percentage points for French firms. These differences are estimated to be statistically significant at 1 percent level and suggest that the increase in the profit ratio gap for German affiliates may be linked with a larger fraction of those companies reporting zero taxable profits in the United Kingdom. These results are consistent with findings for the United Kingdom on the importance of zero taxable profit reporting and in line with the fixed cost of profit shifting hypothesis. Another possible explanation that is consistent with those findings is that variable cost of shifting profits has fallen over time. This cost could involve an improving digital technology that allows the spread of avoidance techniques.

I explore differences in the ratio of taxable profits to total assets reported by foreign multinational subsidiaries depending on where their headquarters are located. 14 There is evidence in the tax literature that companies with affiliates in tax havens tend to report lower profits in higher tax jurisdictions, which is often interpreted as a sign of profit shifting. If the size of the profit ratio gap is related to profit shifting, I would expect foreign multinational subsidiaries with parents in tax havens to be reporting lower ratios of taxable profits to total assets in the United Kingdom than foreign multinational subsidiaries with parents in higher tax countries.

\footnotetext{
${ }^{14}$ The headquarter is defined here as a company that owns more than 50 percent of the shares of the UK subsidiary. If the owner in an individual or a company only owns minority of the shares, these subsidiaries are excluded from this part of the analysis.
} 
TABle 5-PSM Results: Headquarter Location Heterogeneity

\begin{tabular}{lccccc}
\hline \hline Subsample & Multinational & Domestic & Diff. & SE & Observations \\
\hline Tax haven & 0.096 & 0.224 & -0.128 & 0.004 & 55,516 \\
Large tax haven HK SG NL IE & 0.097 & 0.206 & -0.110 & 0.003 & 63,844 \\
Asian multinationals & 0.076 & 0.177 & -0.100 & 0.004 & 32,024 \\
French multinationals & 0.091 & 0.176 & -0.085 & 0.005 & 19,322 \\
US multinational & 0.115 & 0.195 & -0.080 & 0.004 & 106,122 \\
German multinationals & 0.089 & 0.165 & -0.075 & 0.006 & 22,334 \\
Other European multinationals & 0.128 & 0.190 & -0.062 & 0.019 & 41,520 \\
Other foreign multinationals & 0.159 & 0.208 & -0.048 & 0.080 & 41,590 \\
\hline
\end{tabular}

Notes: Results from the Propensity Score Matching estimates, using total assets and within industry as matching variables. I perform matching for each headquarter subsample to find comparable domestic standalones. The outcome variable is taxable profits/total assets in each row. Observations column is a sum of total number of observations, which are split equally between the two ownership types. Selected sample, 2000-2014.

Sources: Merged HMRC and FAME data

I divide the sample of foreign multinational subsidiaries according to the location of their global ultimate owner. I use these particular headquarter locations as these countries have the largest number of affiliates in the United Kingdom and some, such as the United States, Germany, and France, are considered high tax countries. I then perform matching separately for each of those subgroups of foreign multinational subsidiaries finding the best match among all domestic standalones. I use the whole population of domestic standalones for each of the subgroups of foreign multinational subsidiaries with various headquarter locations, hence the same domestic standalone can be used in each subsample. I distinguish between the following headquarter locations: tax haven (excluding large tax havens), large tax haven such as Hong Kong, Singapore, the Netherlands, and Ireland, French multinationals, German multinationals, other European multinationals, US multinationals, Asian multinationals, other foreign multinationals.

The results from this matching procedure are reported in Table 5 and are ranked according to the size of the estimated profit ratio gap, from largest to smallest. I find that foreign multinational subsidiaries headquartered in tax havens report the lowest ratios of taxable profits to total assets in the United Kingdom relative to domestic standalones (the size of the profit ratio gap is -12.8 percentage points). They are followed by foreign multinational subsidiaries headquartered in large tax havens. The smallest difference to domestic standalones, by far, is reported by other foreign multinationals $(-4.8$ percentage points).

\section{Conclusion}

This paper uses the administrative corporate tax returns data to show that foreign multinational companies report lower ratios of taxable profits to total assets than comparable domestic standalone companies. The propensity score matching approach controls for the differences between the two groups coming from size and industry variation, and estimates the remainder of the difference to be 12 percentage points. Assuming that similar-sized companies from similar industries should be reporting similar taxable profits, unless they are involved in practices that aim at minimizing their tax liability in the United Kingdom, the difference estimated in 
this paper suggests that foreign multinational subsidiaries shift a large proportion of their taxable profits out of the United Kingdom. Specifically, the baseline propensity score estimates suggest that foreign multinational subsidiaries underreport their taxable profits by about 50 percent relative to domestic standalones. I show that the size of this difference is sensitive to changes in corporate tax rates, which implies that what I measure is likely to be the size of the potential profit shifting of the UK companies.

Using the net tax payable from the tax returns together with the implied estimates of the size of the difference in the ratio of taxable profits to total assets, I can calculate the implied revenue gain from equalizing the tax treatment of profits of domestic standalones and foreign multinationals. These welfare gain calculations could help to understand the gains that can be obtained from introducing the destination base cash flow tax (DBCFT, see Auerbach et al. 2017, Auerbach 2017). This tax aims at elimination of the current channels of profit shifting and equalization of the tax treatment of foreign and domestic companies. In particular, the proposals suggest taxing only profits based on activities performed in a given country with a border adjustment that would effectively deny a tax deduction for imported inputs. This means that DBCFT would completely eliminate incentives for using transfer pricing manipulation. The proposals, such as DBCFT, do not eliminate the incentive to use interest deductibility completely. However, the importance of debt shifting in the United Kingdom has been declining over time. Together with the recently introduced restrictions on interest deductibility for multinational companies in the United Kingdom with reforms in 2010 and 2017, this would go a long way in equalizing the tax treatment of multinational and domestic firms.

From the yearly matching estimates, we know that the size of the profit ratio gap varies between 30 and 70 percent. Back-of-the-envelope calculations show that the potential revenue gains from equalizing the tax payments of foreign multinational subsidiaries and domestic standalones would vary from $£ 3$ billion at the beginning of the sample to $£ 25$ billion in 2014 . Relative to the total UK corporate tax revenue, which was $£ 30$ billion in 2000 and $£ 40$ billion in 2014 , this would imply that a full elimination of the differences in the reported taxable profits between domestic standalones and foreign multinational subsidiaries would lead to revenue gains of 10 percent in 2000 and 62 percent in 2014, absent behavioral changes.

According to the propensity score matching estimates, the majority of the profit ratio gap can be attributed to the large fraction of zero taxable profit reporting companies amongst foreign multinationals. Once multinational companies report positive taxable profits, their reporting behavior does not differ substantially from that of domestic standalones. This suggests that most of the profit shifting is actually quite aggressive and occurs via reporting zero taxable profits.

These findings have implications for the theoretical modeling of profit shifting costs. If zero taxable profits are prevalent and they explain most of the difference in the taxable profit reporting behavior between foreign multinational subsidiaries and domestic standalones, then modeling the costs of profit shifting as a convex function of profits may not be appropriate. Instead, the assumption of fixed costs of profit shifting, or at least nonconvex ones, should be considered as an alternative. This assumption would mean that firms would be less responsive to the marginal tax rate changes than in a traditional model with convex costs of profit shifting, as 
they bear a fixed cost of shifting profits and once they are large enough to incur that, they report no taxable profits and no further changes in those profits either. This may explain why the recent work using firm-level data does not find large effects of tax rate changes on profits reported by firms. In contrast, majority of the previous literature that used aggregate data has found large responses. These large aggregate responses may come from firms near the fixed cost of profit shifting kink switching in and out of reporting positive taxable profits in response to tax changes. These may be thought of as the extensive margin responses.

I further find that the previous estimates of profit shifting based on the accounting data might be underestimating the true size of the problem. The extent of zero taxable profit reporting is much larger than near-zero accounting profit reporting for foreign multinational subsidiaries, but not for domestic standalones. A more rigorous comparison of taxable and accounting data is outside the scope of this paper. However, using tax returns data instead of accounting data could shed more light on the exact magnitudes of the effects previously described in the profit shifting literature and is an interesting avenue for further research.

I also estimate that about 40 percent of the profit ratio gap comes from differences in leverage between ownership types. I show that the size of the gap that can be explained by leverage has declined over time, as the UK tax rates have also declined making the United Kingdom a less preferred destination to shift debt into. The responsiveness of the differences in leverage to changes in tax rates suggests that these differences may be linked to debt shifting. This could mean that up to 40 percent of foreign multinational profit shifting in the United Kingdom may be explained by debt shifting.

Finally, the estimate of the size of profit shifting presented in this paper is likely to be an underestimate of the true size of profit shifting of all foreign multinational subsidiaries. This is because the propensity score matching leads to an exclusion of the very large foreign multinational subsidiaries (since no comparable domestic standalones exist) that report much lower ratios of taxable profits to total assets than the smaller foreign multinational subsidiaries in the matched sample. Specifically, the unweighted ratio of taxable profits to total assets is 5.6 percent for the very large, unmatched foreign multinational subsidiaries, less than half of the ratio for foreign multinational subsidiaries in the propensity score matched sample. This is inevitably more speculative since I do not have large enough domestic standalones to compare them to the largest multinationals and hence, I am unable to say whether larger domestic standalones would have also reported lower taxable profits as a fraction of their size.

\section{Appendix A. Robustness Checks}

In this section I test the robustness of the baseline estimates of the profit ratio gap (Table 9). I first consider how various first-stage matching specifications affect the main result. I use nonlinear forms of total assets, such as square and cube of the logarithms. Instead of matching within each year, I use a cross-section regression with one observation for each firm, and with the average logarithm of total assets over the sample period to identify the matched observations, i.e., I match on static data so that a company is either always in the control or in the treatment group. I 
further test whether the estimates are robust to disaggregated industries and hence match using three-digit rather than two-digit industry codes. These changes to the first-stage matching procedure alter the estimates of the profit ratio gap to a very small extent. The estimated size of the difference between ownership types varies between 10 and 13 percentage points.

One might be concerned that the taxable profits of multinational companies could be affected by their overseas income. Specifically, overseas income as reported in the tax returns is calculated before double tax relief. This means that part of that overseas income is not actually liable to corporation tax and hence I may be overstating income of foreign multinational subsidiaries by not accounting for the sheltered portion of that income. To understand the effect that the overseas income may have on my results, I exclude profits sheltered by double tax relief from the taxable profits numbers. This does not change the estimate of the profit ratio gap. I exclude from the analysis profits of North Sea oil rig companies that are subject to different regulatory and tax regimes (so-called ring fenced profits). In a similar spirit, I exclude the mining sector, since I documented previously in Bilicka (2017) that companies from that sector report incomparably high ratios of taxable profits to total assets. These exclusions do not change the results significantly.

I further exclude companies that report to have positive equity investments on their balance sheets as part of their fixed assets number. This number is an approximate for equity value of their subsidiaries. This effectively excludes all companies that may have any subsidiaries, but which reported no information on this in the ownership data and hence have not been excluded during the sample selection process; 29 percent of foreign multinational subsidiaries and 5 percent of domestic standalones report data on investments in the FAME dataset. The exclusion of investments from the total assets measure reduces the estimated size of the gap to just over 30 percent, but it also changes substantially the number of observations in the sample as it only includes larger firms, which report lower ratios of taxable profits to total assets in the first place.

The UK system treats losses asymmetrically and when the company makes losses it reports zero taxable profits on its tax return. The firm can recover a portion of those losses once it becomes profitable again by carrying them forward and offsetting them against its future taxable profits. To do so, it has to record those losses on its tax return, which allows me to reconcile the companies which report exactly zero taxable profits with those making losses. However, even after excluding companies which reported losses in the current period and hence are not liable to pay any corporation tax this period, 22 percent of foreign multinational companies report zero taxable profits relative to only 8 percent of domestic standalones. I consider matching using only the subsample of companies that report no losses to make sure that my estimates are not driven by loss making firms. The estimated difference is 10 percentage points, which implies that foreign multinational subsidiaries report 36 percent lower ratio of taxable profits to total assets than domestic standalones. This suggests that the baseline results are indeed driven to a large extent by the zero taxable profit reporting foreign multinationals with no losses. Note that companies could use profit shifting strategies to put themselves into loss making position. Therefore the baseline estimates do include the losses portion of the distribution as well. 
I further explore the results from matching on the ratio of capital allowances to total assets. Another possible explanation for the lower ratio of taxable profits to total assets for multinational companies could be that multinationals invest more than domestic firms. Hence, they may be entitled to legitimate tax deductions such as capital allowances that can be responsible for bringing their profits down. I find that matching on capital allowances in addition to total assets does not alter the estimates of the profit ratio gap relative to the baseline estimates.

In the second part of Table 9 I explore various company size measures which could be used as alternatives to total assets in the first stage of propensity score matching. I use number of employees, fixed assets, and trading turnover. For each of the size variables, I perform PSM twice; first, matching on this alternative size variable and second, comparing the results to matching on total assets on the limited sample of observations for which I have data on each of those alternative size variables. This allows me to examine whether various matching alternatives change the inference in terms of the size of the profit ratio gap.

I find that matching on the number of employees, fixed assets, or trading turnover instead of total assets increases the estimated size of the profit ratio gap twofold. Most of the difference comes from a much higher ratio of taxable profits to total assets for domestic standalones. Foreign multinational subsidiaries in my sample often have a large proportion of their total assets held in intangible assets, while domestic standalones do not hold the same proportion of intangible assets. Therefore, for instance, when matching only on fixed assets, a multinational with large intangible assets that was previously a match for a domestic standalone, with no intangible assets will now be matched with a much smaller domestic standalone company. As I show in Bilicka (2017), smaller domestic standalones tend to report higher ratios of taxable profits to total assets. This explains why the ratio of taxable profits to total assets in the control group is much higher when matching on fixed assets. In case of matching on trading turnover this indicates that domestic standalones, which have similar trading turnover to foreign multinational subsidiaries, report higher taxable profits to total assets ratio than domestic standalones with similar total assets.

Further, I explore what happens when I perform baseline matching analysis using the ratio of trading profits to trading turnover as an outcome variable instead (see the last row in Table 9). Note that assessing the ratio of trading profits to trading turnover comes with multiple caveats, which are discussed in Bilicka (2017). The mean ratio of trading profits to trading turnover for foreign multinational subsidiaries is lower than the ratio of taxable profits to total assets. Since a large proportion of foreign multinational subsidiaries' taxable income comes from sources other than trading profits, we would expect the size of the difference estimated here to be smaller than the one for the ratio of taxable profits to total assets. This seems to be the case, as the estimate of the difference is -7.4 percentage points; i.e., foreign multinational subsidiaries report 45 percent lower ratio of trading profits to trading turnover than domestic standalones.

\section{Appendix B. Consolidated Profits}

One may be concerned that multinational companies can have multiple subsidiaries in the United Kingdom and can choose to locate all of their taxable profits in 
Table 6-Propensity Score Matching: Consolidated Profits Results

\begin{tabular}{lcccccc}
\hline \hline Sample & Variable & Multinational & Domestic & Diff. & SE & Observations \\
\hline Baseline & $y$ & 0.100 & 0.252 & -0.152 & 0.002 & 162,992 \\
Baseline & $y>0$ & 0.179 & 0.212 & -0.033 & 0.003 & 90,668 \\
Baseline & $z t p$ & 0.449 & 0.201 & 0.248 & 0.002 & 162,992 \\
Positive taxable profits & $y$ & 0.179 & 0.213 & -0.034 & 0.003 & 90,668 \\
\hline
\end{tabular}

Notes: Results from the propensity score matching estimation using consolidated data on profits and assets, 2000-2014, selected sample. Matching on total assets and within industry and year. Baseline sample estimates unconditional means, Positive taxable profits sample estimates means conditional on positive taxable profits, ztp is zero taxable profits. Treated observations are foreign multinational subsidiaries, control observations are domestic standalones. Observations column is a sum of total number of observations, which are split equally between the two ownership types.

Sources: Merged HMRC and FAME data

one of those subsidiaries and report zero taxable profits in their remaining affiliates. This is a concern especially since a large number of foreign multinational subsidiaries in the UK report zero taxable profits. A direct way to alleviate this concern is to aggregate data on UK groups of companies using information on who their parent company is. In this section I show the results from this approach. I add up all the taxable profits of UK subsidiaries belonging to the same multinational parent and do the same with their total assets. I then divide one over the other to arrive at the consolidated ratio of taxable profits to total assets for each multinational group. Note that the issues of double counting of total assets arise, if one company in the group owns another. Further, since, the ownership data do not have full coverage of all ownership links in the United Kingdom, aggregating companies into groups is likely to introduce a measurement error.

In Table 6 I show that the matching procedure using consolidated data yields larger estimates of the profit ratio gap. The mean ratio of taxable profits to total assets for foreign multinational subsidiaries is 10 percent, while that ratio is 25.2 percent for domestic standalones. This means that the size of the gap in taxable profits between the ownership types is 15.2 percentage points, i.e., multinationals underreport their taxable profits by 60 percent. These larger estimates are driven by smaller ratios of taxable profits to total assets reported by foreign multinational subsidiaries. This is to be expected, as these subsidiaries may be owned by each other and hence I may be double counting their total assets. Since the difference in the proportion of zero taxable profit reporting companies even on the consolidated basis is very large, these results show that the baseline estimates are not driven by multiple subsidiaries of the same company reporting zero taxable profits.

\section{Appendix C. Size Differences}

In this section I consider the heterogeneity of the estimates by size bins. I divide the sample of foreign multinational subsidiaries and domestic standalones into ten equally-sized size bins based on the size of their total assets in the United Kingdom. Within each bin, I perform the baseline propensity score matching. This gives me 20 different ratios of taxable profits to total assets, 10 for foreign multinational 
TABLE 7-PSM Results: Size Bins

\begin{tabular}{lcccccc}
\hline \hline Size quantile & Multinational & Domestic & Diff. & SE & Observations & Implied gap \\
\hline 1 & 1.216 & 1.333 & -0.117 & 0.753 & 4,788 & $-8.8 \%$ \\
2 & 0.436 & 1.044 & -0.608 & 0.145 & 5,908 & $-58.2 \%$ \\
3 & 0.288 & 0.978 & -0.690 & 0.059 & 6,238 & $-70.5 \%$ \\
4 & 0.158 & 0.740 & -0.582 & 0.026 & 7,842 & $-78.7 \%$ \\
5 & 0.151 & 0.566 & -0.414 & 0.015 & 11,232 & $-73.2 \%$ \\
6 & 0.136 & 0.388 & -0.251 & 0.009 & 17,086 & $-64.8 \%$ \\
7 & 0.123 & 0.281 & -0.158 & 0.004 & 28,690 & $-56.3 \%$ \\
8 & 0.109 & 0.198 & -0.090 & 0.003 & 48,100 & $-45.2 \%$ \\
9 & 0.088 & 0.140 & -0.052 & 0.001 & 87,374 & $-37.2 \%$ \\
10 & 0.058 & 0.082 & -0.024 & 0.002 & 200,520 & $-29.1 \%$ \\
\hline
\end{tabular}

Notes: Results from the Propensity Score Matching estimates. Matching on total assets and within industry and year. Each row corresponds to one of the ten different size quantiles, 1 is the smallest, 10 the largest. Matching is performed separately in each size quantile. The outcome variable is taxable profits/total assets in each row. Observations column is a sum of total number of observations, which are split equally between the two ownership types. Selected sample, 2000-2014.

Sources: Merged HMRC and FAME data

subsidiaries in each size bin and 10 for comparable domestic standalones in each of those size bins.

The results in Table 7 suggest that the size of the profit ratio gap declines as companies get larger, the only exception being the very smallest companies in size bins 1 and 2. Further, the ratios of taxable profits to total assets for both ownership categories get smaller as the company size increases. However, the implied gap in the ratio of taxable profits to total assets between foreign multinational subsidiaries and domestic standalones increases initially as companies get larger up to the median sized company. The largest gap is observed for companies in the fourth size quantile and is 78.7 percent. Following that, the implied gap starts falling and reaches its lowest for the largest companies in size bin 10. These results come with a caveat. Because the largest multinational companies are excluded from the analysis the size of the gap across increasing size bins may not be monotonic as one may expect.

\section{Appendix D. Alternative Matching Approaches}

In this section I explore whether the chosen matching algorithm affects the size of the estimated profit ratio gap. Using more observations as a control group increases the efficiency of the estimates, but might affect the bias of the coefficient. The replacement feature enables the same domestic standalone to be used as a comparable company for foreign multinational subsidiaries multiple of times. This might be important in the right hand side tail of the distribution where there are not very many large domestic standalones to create a comparable group for foreign multinational subsidiaries. Using matching with replacement does not substantially change the size of the estimated difference, irrespective of whether I use 1, 3, 5, or 10 nearest neighbors. The mean ratios of taxable profits for both domestic and multinational companies are smaller, 20 percent and 10 percent respectively, which implies that the size of the difference between them is still 50 percent.

There are various other algorithms which can be used to obtain matched samples based on the propensity scores, such as kernel, radius, and local linear matching. 
Table 8-Alternative Matching Approaches: Robustness Tests

\begin{tabular}{lccccc}
\hline \hline Sample & Multinational & Domestic & Diff. & SE & Observations \\
\hline Nearest neighbors with replacement & 0.103 & 0.196 & -0.092 & 0.008 & $4,213,900$ \\
3-nearest neighbors & 0.103 & 0.206 & -0.103 & 0.009 & $4,213,900$ \\
5-nearest neighbors & 0.103 & 0.211 & -0.108 & 0.009 & $4,213,900$ \\
10-nearest neighbors & 0.103 & 0.209 & -0.106 & 0.010 & $4,213,900$ \\
Radius & 0.103 & 0.300 & -0.197 & 0.017 & $4,213,900$ \\
Local linear matching & 0.103 & 0.237 & -0.133 & 0.009 & $4,213,900$ \\
Kernel & 0.103 & 0.316 & -0.213 & 0.016 & $4,213,900$ \\
\hline
\end{tabular}

Notes: Results from the propensity score matching estimation using unconsolidated data on profits and assets, 2000-2014, selected sample. Matching on total assets and within industry and year. Each row corresponds to a different matching algorithm. Treated observations are foreign multinational subsidiaries, control observations are domestic standalones. Observations column is a sum of total number of observations, which are now not necessarily split evenly between multinational and domestic firms.

Sources: Merged HMRC and FAME data

Radius matching uses all domestic standalone companies with propensity scores within a certain radius from a given multinational to estimate the size of the difference. Kernel and local linear matching use all domestic standalones, but weight the control observations inverse-proportionally to the propensity score difference to the multinational company. Kernel matching uses intercept to produce the weights, while local linear matching in addition to the intercept includes a linear term. Using more observations for matching increases precision, but the more observations you use the less suitable they are as comparisons. This could lead to large biases. The evidence from Bilicka (2017) shows that larger multinationals are not comparable to smaller ones in terms of the ratio of their taxable profits to total assets. Hence, I use the nearest neighborhood matching as my preferred strategy, to avoid large biases and trade off efficiency of the estimates. However, as Table 8 shows, using various matching algorithms does not affect the implied size of the profit ratio gap; it remains persistently around 50-60 percent. 
TABLE 9-PSM: Robustness TESTS

\begin{tabular}{|c|c|c|c|c|c|c|}
\hline Sample & Variable & Treated & Control & Diff. & SE & Observations \\
\hline \multicolumn{7}{|l|}{ Panel A. Robustness checks } \\
\hline First-stage total assets enter as a square & $\begin{array}{l}\text { Taxable profits/ } \\
\text { total assets }\end{array}$ & 0.120 & 0.236 & -0.116 & 0.011 & 324,736 \\
\hline $\begin{array}{l}\text { First-stage total assets enter as a square } \\
\text { and a cube }\end{array}$ & $\begin{array}{l}\text { Taxable profits/ } \\
\text { total assets }\end{array}$ & 0.120 & 0.237 & -0.117 & 0.011 & 324,736 \\
\hline Matching on static data in logit model & $\begin{array}{l}\text { Taxable profits/ } \\
\text { total assets }\end{array}$ & 0.118 & 0.249 & -0.131 & 0.011 & 324,736 \\
\hline First stage: three-digit industry & $\begin{array}{l}\text { Taxable profits/ } \\
\text { total assets }\end{array}$ & 0.101 & 0.229 & -0.128 & 0.008 & 324,736 \\
\hline First stage: four-digit industry & $\begin{array}{l}\text { Taxable profits } / \\
\text { total assets }\end{array}$ & 0.100 & 0.261 & -0.161 & 0.008 & 324,736 \\
\hline $\begin{array}{l}\text { Taxable profits less those } \\
\text { sheltered by dtr }\end{array}$ & $\begin{array}{l}\text { Taxable profits/ } \\
\text { total assets }\end{array}$ & 0.119 & 0.237 & -0.118 & 0.011 & 324,736 \\
\hline $\begin{array}{l}\text { Exclude companies with ring } \\
\text { fenced profits }\end{array}$ & $\begin{array}{l}\text { Taxable profits } / \\
\text { total assets }\end{array}$ & 0.118 & 0.237 & -0.119 & 0.011 & 324,724 \\
\hline Exclude mining sector & $\begin{array}{l}\text { Taxable profits/ } \\
\text { total assets }\end{array}$ & 0.119 & 0.240 & -0.121 & 0.011 & 321,932 \\
\hline $\begin{array}{l}\text { Exclude companies with positive } \\
\text { equity investments }\end{array}$ & $\begin{array}{l}\text { Taxable profits } / \\
\text { total assets }\end{array}$ & 0.094 & 0.138 & -0.044 & 0.007 & 28,100 \\
\hline $\begin{array}{l}\text { Match of companies which report } \\
\text { zero trading loss }\end{array}$ & $\begin{array}{l}\text { Taxable profits } / \\
\text { total assets }\end{array}$ & 0.172 & 0.275 & -0.103 & 0.015 & 225,830 \\
\hline Match on capital allowance & $\begin{array}{l}\text { Taxable profits/ } \\
\text { total assets }\end{array}$ & 0.120 & 0.242 & -0.122 & 0.011 & 324,736 \\
\hline Foreign multis versus domestic groups & $\begin{array}{l}\text { Taxable profits/ } \\
\text { total assets }\end{array}$ & 0.120 & 0.137 & -0.017 & 0.018 & 268,420 \\
\hline \multicolumn{7}{|c|}{ Panel B. Different size measures (instead of total assets) } \\
\hline Match on employment & $\begin{array}{l}\text { Taxable profits } \\
\text { total assets }\end{array}$ & 0.082 & 0.238 & -0.156 & 0.022 & 84,840 \\
\hline Baseline (employment sample) & $\begin{array}{l}\text { Taxable profits } / \\
\text { total assets }\end{array}$ & 0.103 & 0.164 & -0.061 & 0.009 & 73,822 \\
\hline Match on fixed assets & $\begin{array}{l}\text { Taxable profits/ } \\
\text { total assets }\end{array}$ & 0.088 & 0.256 & -0.169 & 0.001 & 295,374 \\
\hline Baseline (fixed assets sample) & $\begin{array}{l}\text { Taxable profits/ } \\
\text { total assets }\end{array}$ & 0.094 & 0.176 & -0.082 & 0.001 & 243,466 \\
\hline Match on trading turnover & $\begin{array}{l}\text { Taxable profits/ } \\
\text { total assets }\end{array}$ & 0.110 & 0.342 & -0.233 & 0.012 & 283,196 \\
\hline Baseline (trading turnover sample) & $\begin{array}{l}\text { Taxable profits/ } \\
\text { total assets }\end{array}$ & 0.106 & 0.235 & -0.129 & 0.003 & 320,744 \\
\hline Baseline (trading turnover sample) & $\begin{array}{l}\text { Trading profits/ } \\
\text { trading turnover }\end{array}$ & 0.091 & 0.166 & -0.074 & 0.000 & 320,744 \\
\hline
\end{tabular}

Notes: Results from the Propensity Score Matching estimates, various robustness tests. In panel A, I show results from robustness specifications. In panel B, I show results using alternative size measures instead of total assets in the first stage of PSM. The first row in panel B refers to matching on employment instead of total assets, the second row to matching on total assets, but using only the sample for which employment observations are available. The remaining rows perform the same comparison, using fixed assets and trading turnover. Treated observations are foreign multinational subsidiaries, control observations are domestic standalones. Observations column is a sum of total number of observations, which are split equally between the two ownership types. Selected sample, 2000-2014.

Sources: Merged HMRC and FAME data 
TABle 10-Changes in LeVerage over Time

\begin{tabular}{|c|c|c|c|c|}
\hline Year & $\begin{array}{l}\text { Diff. } \\
\text { in } y\end{array}$ & $\begin{array}{c}\text { Diff. in } y \\
\text { (control for leverage) }\end{array}$ & $\begin{array}{l}\text { Explained var. } \\
\text { (in percent) }\end{array}$ & Observations \\
\hline 2004 & $\begin{array}{c}-0.031 \\
(0.003)\end{array}$ & $\begin{array}{c}-0.016 \\
(0.003)\end{array}$ & 49 & 6,950 \\
\hline 2005 & $\begin{array}{c}-0.042 \\
(0.003)\end{array}$ & $\begin{array}{c}-0.021 \\
(0.004)\end{array}$ & 50 & 7,190 \\
\hline 2006 & $\begin{array}{r}-0.042 \\
(0.003)\end{array}$ & $\begin{array}{r}-0.016 \\
(0.003)\end{array}$ & 61 & 8,320 \\
\hline 2007 & $\begin{array}{c}-0.039 \\
(0.003)\end{array}$ & $\begin{array}{c}-0.024 \\
(0.004)\end{array}$ & 36 & 8,816 \\
\hline 2008 & $\begin{array}{c}-0.048 \\
(0.003)\end{array}$ & $\begin{array}{c}-0.025 \\
(0.003)\end{array}$ & 48 & 9,220 \\
\hline 2009 & $\begin{array}{c}-0.053 \\
(0.003)\end{array}$ & $\begin{array}{c}-0.030 \\
(0.003)\end{array}$ & 43 & 9,444 \\
\hline 2010 & $\begin{array}{c}-0.044 \\
(0.003)\end{array}$ & $\begin{array}{r}-0.038 \\
(0.013)\end{array}$ & 12 & 9,682 \\
\hline 2011 & $\begin{array}{r}-0.056 \\
(0.003)\end{array}$ & $\begin{array}{c}-0.043 \\
(0.003)\end{array}$ & 23 & 9,916 \\
\hline 2012 & $\begin{array}{c}-0.064 \\
(0.003)\end{array}$ & $\begin{array}{c}-0.050 \\
(0.003)\end{array}$ & 23 & 9,820 \\
\hline 2013 & $\begin{array}{c}-0.057 \\
(0.003)\end{array}$ & $\begin{array}{r}-0.040 \\
(0.003)\end{array}$ & 30 & 9,364 \\
\hline 2014 & $\begin{array}{c}-0.062 \\
(0.003)\end{array}$ & $\begin{array}{c}-0.041 \\
(0.003)\end{array}$ & 33 & 8,870 \\
\hline
\end{tabular}

Notes: Results from the Propensity Score Matching estimates showing how the use of leverage changed over time. Results show the difference in the PSM estimator between foreign multinational subsidiaries and domestic standalones where the outcome variable is the ratio of taxable profits to total assets. PSM is performed every year separately. The results in column 3 replicate baseline PSM, but on the sample for which the leverage data are available, the results in column 4 use leverage as additional matching variable to total assets and industry. Standard errors of the estimated difference are in parentheses. Observations column is a sum of total number of observations, which are split equally between the two ownership types. Selected sample, 2004-2014.

Sources: Merged HMRC and FAME data 
Panel A. Foreign multinationals 2001

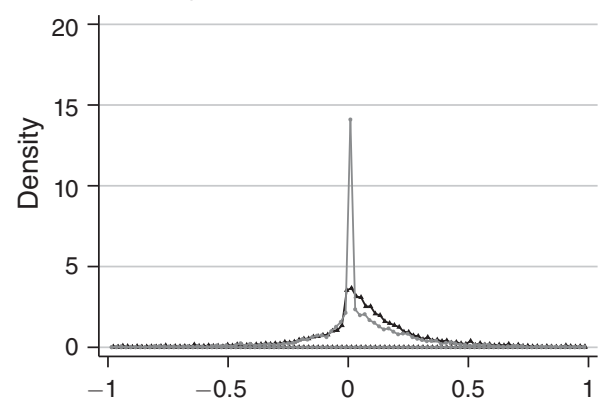

Panel C. Foreign multinationals 2005

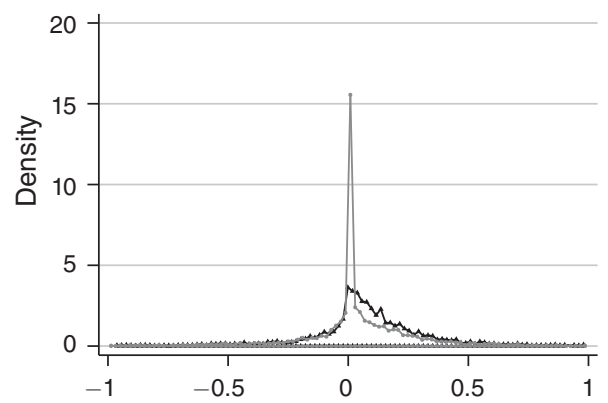

Panel E. Foreign multinationals 2009

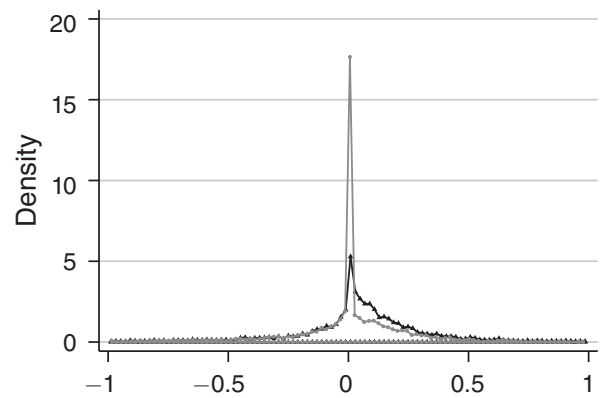

Panel G. Foreign multinationals 2013

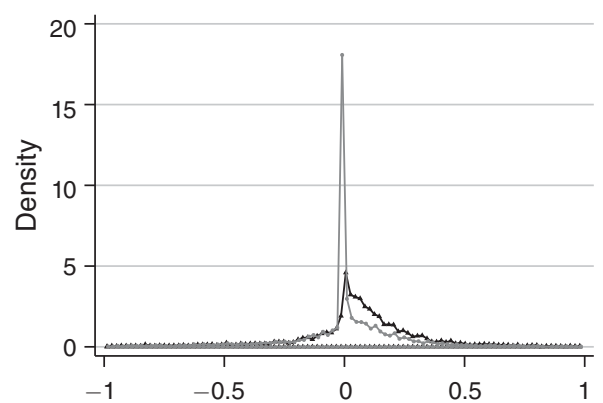

Panel B. Domestic standalones 2001

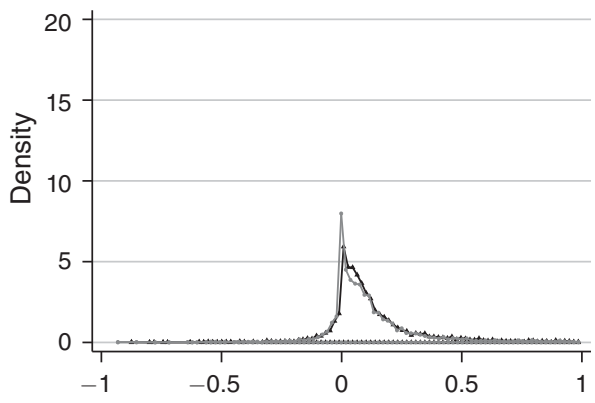

Panel D. Domestic standalones 2005

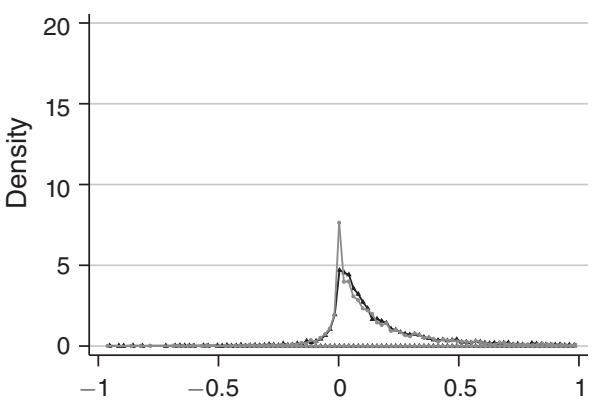

Panel F. Domestic standalones 2009

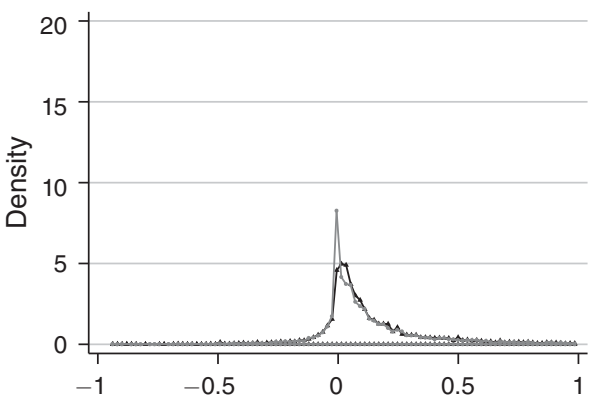

Panel H. Domestic standalones 2013

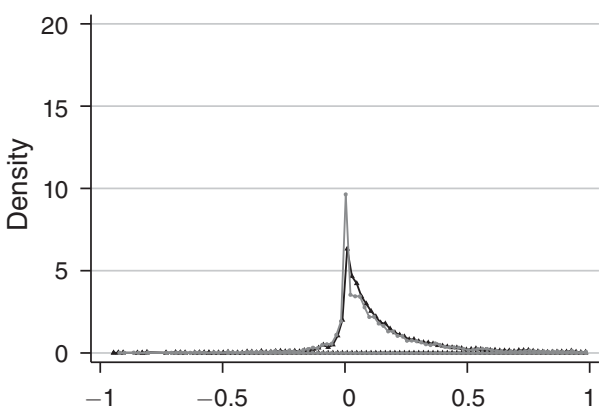

Figure 4. Distributions of Taxable and Accounting Profits: Comparisons over Time

Notes: Distribution of the ratios of taxable profits (including trading losses) from HMRC and profit and loss before taxes from FAME scaled by total assets, propensity score matched sample with non-missing accounting profits data, 2000-2014. The gray line represents taxable profits, the black line represents accounting profits. 


\section{REFERENCES}

- Abadie, Alberto, and Guido W. Imbens. 2006. "Large Sample Properties of Matching Estimators for Average Treatment Effects." Econometrica 74 (1): 235-67.

Abadie, Alberto, and Guido W. Imbens. 2008. "On the Failure of the Bootstrap for Matching Estimators." Econometrica 76 (6): 1537-57.

- Abadie, Alberto, and Guido W. Imbens. 2016. "Matching on the Estimated Propensity Score." Econometrica 84 (2): 781-807.

- Aitken, Brian J., and Ann E. Harrison. 1999. "Do Domestic Firms Benefit from Direct Foreign Investment? Evidence from Venezuela." American Economic Review 89 (3): 605-18.

- Altshuler, Rosanne, Alan J. Auerbach, Michael Cooper, and Matthew Knittel. 2009. "Understanding US Corporate Tax Losses." Tax Policy and the Economy 23 (1): 73-122.

-Armstrong, Christopher S., Jennifer L. Blouin, Alan D. Jagolinzer, and David F. Larcker. 2015. "Corporate Governance, Incentives, and Tax Avoidance.” Journal of Accounting and Economics 60 (1): $1-17$.

Armstrong, Christopher S., Jennifer L. Blouin, and David F. Larcker. 2012. "The Incentives for Tax Planning." Journal of Accounting and Economics 53 (1-2): 391-411.

Auerbach, Alan J. 2017. "Demystifying the Destination-Based Cash-Flow Tax." NBER Working Paper 23881.

Auerbach, Alan J., Michael P. Devereux, Michael Keen, and John Vella. 2017. "Destination-Based Cash Flow Taxation.” Oxford University Centre for Business Taxation Working Paper WP 17/01.

Bilicka, Katarzyna. 2017. "How Much Tax Do Companies Pay in the UK? Evidence from UK Confidential Corporate Tax Returns." Unpublished.

Bilicka, Katarzyna Anna. 2019. "Comparing UK Tax Returns of Foreign Multinationals to Matched Domestic Firms: Dataset." American Economic Review. https://doi.org/10.1257/aer.20180496.

Bilicka, Katarzyna, Yaxuan Qi, and Jing Xing. 2019. "Debt Shifting Restrictions and Reallocation of Debt." Unpublished.

Blouin, Jennifer, Harry Huizinga, Luc Laeven, and Gaëtan Nicodème. 2014. "Thin Capitalization Rules and Multinational Firm Capital Structure.” Directorate General Taxation and Customs Union, European Commission Taxation Paper 42.

- Clausing, Kimberly A. 2016. "The Effect of Profit Shifting on the Corporate Tax Base in the United States and Beyond." National Tax Journal 69 (4): 905-34.

Cochran, William G., and Donald B. Rubin. 1973. "Controlling Bias in Observational Studies: A Review." Indian Journal of Statistics Series A 35 (4): 417-46.

-Cristea, Anca D., and Daniel X. Nguyen. 2016. "Transfer Pricing by Multinational Firms: New Evidence from Foreign Firm Ownerships.” American Economic Journal: Economic Policy 8 (3): 170-202.

Davies, Ronald B., Julien Martin, Mathieu Parenti, and Farid Toubal. 2018. "Knocking on Tax Haven's Door: Multinational Firms and Transfer Pricing." Review of Economics and Statistics 100 (1): 120-34.

Desai, Mihir A., and Dhammika Dharmapala. 2009. "Earnings Management, Corporate Tax Shelters, and Book-Tax Alignment.” National Tax Journal 62 (1): 169-86.

Desai, Mihir A., C. Fritz Foley, and James R. Hines. 2006. "The Demand for Tax Haven Operations." Journal of Public Economics 90 (3): 513-31.

Dharmapala, Dhammika. 2014. "What Do We Know about Base Erosion and Profit Shifting? A Review of the Empirical Literature.” Fiscal Studies 35 (4): 421-48.

Dharmapala, Dhammika, and Shafik Hebous. 2018. "A Bunching Approach to Measuring Multinational Profit Shifting." Unpublished.

Dharmapala, Dhammika, and Nadine Riedel. 2013. "Earnings Shocks and Tax-Motivated Income-Shifting: Evidence from European Multinationals." Journal of Public Economics 97: 95-107.

Dischinger, Matthias, Bodo Knoll, and Nadine Riedel. 2014. "There's No Place Like Home: The Profitability Gap between Headquarters and Their Foreign Subsidiaries." Journal of Economics \& Management Strategy 23 (2): 369-95.

Dischinger, Matthias, and Nadine Riedel. 2011. "Corporate Taxes and the Location of Intangible Assets within Multinational Firms.” Journal of Public Economics 95 (7-8): 691-707.

Dowd, Tim, Paul Landefeld, and Anne Moore. 2017. "Profit Shifting of US Multinationals." Journal of Public Economics 148: 1-13.

Dyreng, Scott D., Michelle Hanlon, Edward L. Maydew, and Jacob R. Thornock. 2017. "Changes in Corporate Effective Tax Rates over the Past 25 Years." Journal of Financial Economics 124 (3): 441-63.

-Egger, Peter, Wolfgang Eggert, and Hannes Winner. 2010. "Saving Taxes through Foreign Plant Ownership.” Journal of International Economics 81 (1): 99-108. 
Evers, Maria, Ina Meier, and Katharina Nicolay. 2017. "The Implications of Book-Tax Differences: A Meta-Analysis." Unpublished.

-Graham, John R., Jana S. Raedy, and Douglas A. Shackelford. 2012. "Research in Accounting for Income Taxes." Journal of Accounting and Economics 53 (1-2): 412-34.

Grubert, Harry. 1998. "Another Look at the Low Taxable Income of Foreign-Controlled Companies in the United States." Proceedings. Annual Conference on Taxation and Minutes of the Annual Meeting of the National Tax Association 91: 157-75.

- Grubert, Harry. 2003. "Intangible Income, Intercompany Transactions, Income Shifting, and the Choice of Location." National Tax Journal 56 (1): 221-42.

Grubert, Harry, Timothy Goodspeed, and Deborah L. Swenson. 1993. "Explaining the Low Taxable Income of Foreign-Controlled Companies in the United States." In Studies in International Taxation, edited by Alberto Giovannini et al., 237-76. Chicago: University of Chicago Press.

-Grubert, Harry, and Joel Slemrod. 1998. "The Effect of Taxes on Investment and Income Shifting to Puerto Rico." Review of Economics and Statistics 80 (3): 365-73.

-Gumpert, Anna, James R. Hines, and Monika Schnitzer. 2016. "Multinational Firms and Tax Havens." Review of Economics and Statistics 98 (4): 713-27.

-Hanlon, Michelle. 2003. "What Can We Infer about a Firm's Taxable Income from Its Financial Statements?" National Tax Journal 56 (4): 831-63.

-Hanlon, Michelle, and Shane Heitzman. 2010. "A Review of Tax Research.” Journal of Accounting and Economics 50 (2-3): 127-78.

-Heckemeyer, Jost H., and Michael Overesch. 2017. "Multinationals' Profit Response to Tax Differentials: Effect Size and Shifting Channels." Canadian Journal of Economics/Revue Canadienne d'Economique 50 (4): 965-94.

-Helpman, Elhanan, Marc J. Melitz, and Stephen R. Yeaple. 2004. "Export versus FDI with Heterogeneous Firms." American Economic Review 94 (1): 300-16.

-Hines, James R., and Eric M. Rice. 1994. "Fiscal Paradise: Foreign Tax Havens and American Business." Quarterly Journal of Economics 109 (1): 149-82.

-Imbens, Guido W. 2004. "Nonparametric Estimation of Average Treatment Effects under Exogeneity: A Review." Review of Economics and Statistics 86 (1): 4-29.

-Javorcik, Beata Smarzynska. 2004. "Does Foreign Direct Investment Increase the Productivity of Domestic Firms? In Search of Spillovers through Backward Linkages." American Economic Review 94 (3): 605-27.

Johannesen, Niels, Thomas Tørsløv, and Ludvig Wier. 2016. "Are Less Developed Countries More Exposed to Multinational Tax Avoidance?" Unpublished.

Laster, David S., and Robert N. McCauley. 1994. "Making Sense of the Profits of Foreign Firms in the United States." Quarterly Review 19 (2).

Liu, Li, Tim Schmidt-Eisenlohr, and Dongxian Guo. 2017. "International Transfer Pricing and Tax Avoidance: Evidence from Linked Trade-Tax Statistics in the UK." Unpublished.

-Markusen, James R., and Anthony J. Venables. 1998. "Multinational Firms and the New Trade Theory." Journal of International Economics 46 (2): 183-203.

Mataloni, Raymond J. 2000. "An Examination of the Low Rates of Return of Foreign-Owned U.S. Companies." Survey of Current Business 80 (3): 55-73.

-Mills, Lillian F., and Kaye J. Newberry. 2004. "Do Foreign Multinationals' Tax Incentives Influence Their US Income Reporting and Debt Policy?” National Tax Journal 57 (1): 89-107.

Mills, Lillian, Kaye Newberry, and William B. Trautman. 2002. "Trends in Book-Tax Income and Balance Sheet Differences." Unpublished.

- Rosenbaum, Paul R., and Donald B. Rubin. 1983. "The Central Role of the Propensity Score in Observational Studies for Causal Effects." Biometrika 70 (1): 41-55.

Rosenbaum, Paul R., and Donald B. Rubin. 1985. "Constructing a Control Group Using Multivariate Matched Sampling Methods That Incorporate the Propensity Score.” American Statistician 39 (1): 33-38.

-Sabirianova, Klara, Jan Svejnar, and Katherine Terrell. 2005. "Distance to the Efficiency Frontier and Foreign Direct Investment Spillovers." Journal of the European Economic Association 3 (2-3): $576-86$.

-Slemrod, Joel, and John D. Wilson. 2009. "Tax Competition with Parasitic Tax Havens." Journal of Public Economics 93 (11-12): 1261-70.

Tørsløv, Thomas R., Ludvig S. Wier, and Gabriel Zucman. 2018. "The Missing Profits of Nations." National Bureau of Economic Research Working Paper 24701.

- Yasar, Mahmut, and Catherine J. Morrison Paul. 2007. "International Linkages and Productivity at the Plant Level: Foreign Direct Investment, Exports, Imports and Licensing." Journal of International Economics 71 (2): 373-88. 


\section{This article has been cited by:}

1. Katarzyna Bilicka, André Seidel. 2020. Profit shifting and corruption. International Tax and Public Finance 22. . [Crossref]

2. Ruud de Mooij, Li Liu. 2020. At a Cost: The Real Effects of Transfer Pricing Regulations. IMF Economic Review 68:1, 268-306. [Crossref]

3. Petr Janský, Miroslav Palanský. 2019. Estimating the scale of profit shifting and tax revenue losses related to foreign direct investment. International Tax and Public Finance 26:5, 1048-1103. [Crossref]

4. Kevin Markle, Leslie Robinson. 2018. Negotiated Tax Havens. SSRN Electronic Journal . [Crossref] 